\title{
How responsive are charitable donors to requests to give?*
}

\author{
Barış K. Yörük ${ }^{\dagger}$ \\ Boston College, Department of Economics
}

October 26, 2006

\begin{abstract}
People tend to contribute to a charity only when they are asked to. Although this so-called 'power of asking' is a well-known technique among fundraisers, the existing literature does not pay much attention to the role of donation requests in charitable giving. We estimate the causal effects of charitable solicitations on both the propensity to give and the amount of charitable contributions using a unique data set, which was designed to measure the giving behavior in the United States. In order to address the endogeneity of the donation requests due to non-random solicitation of charitable donors, we link this data set to IRS data on charitable organizations and the 2000 Census and propose identifying instruments. After controlling for the endogeneity, we find that people are both more likely to contribute to a charity and also donate more when they are asked to. This effect is robust under different specifications and with different sets of instruments and is much larger compared with the estimates of univariate models. Furthermore, we argue that some identifiable characteristics of individuals are associated with the higher probability of being solicited. In particular, we find some evidence that income, age, education, and race play significant roles in explaining the selection of potential charitable donors.
\end{abstract}

Keywords: charitable contributions, charitable solicitations, non-profit organizations

JEL Codes: H31, L30, L38

\footnotetext{
${ }^{*}$ I thank Center of Wealth and Philanthrophy at Boston College for providing the data. I am grateful to Ingela Alger, Donald Cox, Shannon Seitz, Tayfun Sönmez, Richard Tresch, and the session participants at the dissertation workshop at Boston College and the annual meeting of the Canadian Economic Association (2006) for their helpful comments and discussions. The usual disclaimer applies.

${ }^{\dagger}$ Boston College, Department of Economics, 140 Commonwealth Ave., Chestnut Hill, MA 02467. Tel: $617-552$ 6134. Fax: 617-552 2308. E-mail: yoruk@bc.edu.
} 


\section{Introduction}

Among many other fundraising techniques ${ }^{1}$, the iron law of fundraising, as Andreoni (2004) refers to it, is asking. People are not only more likely to give, but also tend to donate more when they are asked to. Recent data on charitable activity in the United States show that, on average, charities spend slightly less than a dollar in fundraising expenditures to receive one dollar worth of donation ${ }^{2}$. If in fact generous people are more likely to give, is it possible that all that fundraising money is really money wasted? Although, it is almost a truism among fundraisers that asking facilitates charitable giving $^{3}$, the relationship between charitable solicitations and giving behavior has rarely been studied and efforts to understand the determinants of giving have mostly been limited to investigating the impact of numerous demographic variables, income, and tax price of giving on the amount of charitable contributions.

There are several surveys of empirical studies of giving. These include Clotfelter $(1985,1990)$, Andreoni (2004), and Vesterlund (2006). It is now a stylized fact in the existing literature that better educated individuals with higher incomes are more likely to give and tax price of giving has a negative effect on the amount of charitable gifts. The results on the other determinants of giving are mixed. For example, Duncan (1999) finds that married people tend to give more, whereas Lankford and Wyckkoff (1991) show that marital status is not a significant determinant of giving. Duncan (1999) and Lankford and Wyckkoff (1991) find no significant effect of age on giving behavior, whereas Andreoni, Brown, and Rischall (2003) find that older people are more likely to give. Similar results also prevail for the race and other personal characteristics of charitable donors.

Only recently has the importance of solicitations in charitable giving and volunteering time been recognized. Using a linear probability analysis, Freeman (1997) investigates whether people who are asked to volunteer their time are more likely to volunteer. He finds that the effect of being asked to volunteer on the propensity to volunteer is massive and concludes that being asked by a charity

\footnotetext{
${ }^{1}$ Other fundraising techniques include publicizing donor names and donation amounts (Glazer and Kondrad, 1996; Harbaugh, 1998; and Romano and Yildirim, 2001), raffles (Duncan, 2002), and using seed money and refunds (Andreoni, 1998; List and Lucking-Reiley, 2002).

${ }^{2}$ As of 2004 , public charities reported nearly $\$ 1.1$ trillion in total revenues and just over $\$ 1.0$ trillion in total expenses. Approximately $25 \%$ of total revenues came from contributions of individuals, foundations, and corporations, while approximately $24 \%$ of total expenses are fundraising expenditures. Source: The Urban Institute, National Center for Charitable Statistics, Core Files, 2004.

${ }^{3}$ The power of asking is a well known technique among fundraisers. See, for example, Seymour (1992) and Keegan (1994).
} 
is in fact the single most important reason for why people volunteer their time. He also shows that employed, better educated people with higher incomes are more likely to be asked to volunteer than others and they are also more likely to accede to these requests. Schervish and Havens (1997), estimating an ordinary least squares regression (OLS), show that there is a positive relationship between charitable solicitations and the percentage of income contributed by the household. On the other hand, Bryant et. al. (2003), using a probit analysis, investigate the factors that differentiate people who are asked to give or volunteer from those who are not. They argue that several human, social, cultural and income variables explain who is solicited to give or volunteer.

On the theoretical side, in a recent paper, Andreoni and Payne (2003) develop a model of fundraising that formally incorporates charitable solicitations. Their model assumes that people do not give unless they are solicited. However, their empirical intent is quite different from ours. Instead of focusing on the effect of fundraising efforts on giving behavior, they investigate the variation in fundraising efforts when a charity gets a grant from the government and they conclude that fundraising efforts fall due to crowding out.

Why would someone with a desire to give wait until they are asked by a charity? The existing literature offers two distinct answers to this question. On the one hand, Freeman $(1993,1997)$ and Bryant et. al. (2003) suggest that requests for charitable donations carry some social pressure with them. People are more likely to respond to personal requests than to telephone or mail requests, and to requests from relatives and friends than from strangers. This suggests that charitable giving is a conscience activity, one in which people would not like to participate, but feel morally obligated to do so when they are asked to. On the other hand, Andreoni and Payne (2003) argue that donors have latent demands to give, but because of prohibitive search costs of finding their favorite charity, their demand stays unexpressed until they are solicited. When solicited, this cost is eliminated and the donation is made. However, all these studies share a common underlying hypothesis, that charities randomly select individuals to request donations ${ }^{4}$.

In fact, Schervish and Havens (1997) were the first to recognize that the selection of charitable donors is non-random, yet they fail to incorporate this observation into their empirical methodology. They argue that many of the charitable solicitations arise directly as a result of one's participation in an organization. Furthermore, people are less likely to be influenced by impersonal methods, such

\footnotetext{
${ }^{4}$ In their theoretical model, Andreoni and Payne (2003) assume that any individual is equally likely to be solicited by charitable organizations. In his empirical model, Freeman (1997) assumes that the probability of being solicited by a charity is exogeneously determined.
} 
as solicitations by mail or by phone ${ }^{5}$. Building on these statements, there are at least three reasons to believe that one's probability of being solicited is subject to a selection problem. First, almost all charitable organizations identify and keep track of potential donors by relying upon a number of quantifiable information sources, including their own donor databases. These databases record the information on donors' giving habits as well as the information on personal and demographic characteristics $^{6}$ and serve as a primary tool in selecting target donors to solicit. Second, individuals who have shown an interest in the work of the charity are the potential source of referrals to their peers, who might also be willing to consider contributing to the same charity. Hence, individuals who have a peer relationship with a loyal donor of the charity are more likely to be solicited by that particular charity. Finally, some of the charities have natural potential donors. In particular, colleges solicit their alumni to raise funds or a local church solicits those who regularly attend religious services. Moreover, the possible endogeneity of being informed ${ }^{7}$ has also been recognized by different disciplines. For example, in a recent paper, Lassen (2005) estimates the causal effects of being informed on voter turnout, considering the possibility of endogenous information acquisition.

In general, we hypothesize that most of the fundraising efforts are well-planned and targeted and hence, some people are much more likely to be asked for charitable contributions. The propensity to be solicited by a charity is associated with many identifiable personal and demographic characteristics. However, many unidentifiable characteristics that may be correlated with a higher probability of being solicited, such as group membership, ideology, and social status, may also affect the probability of giving and the contribution amount. Hence, one must take into account the possible endogeneity problem when estimating the casual effects of being solicited on both the propensity to give and the amount of charitable donations.

Empirical studies investigating the effect of solicitations on charitable giving, besides their methodological problems ${ }^{8}$, do not control for this possible endogeneity problem. Part of the reason

\footnotetext{
${ }^{5}$ Professional fundraisers are well aware of this fact. For example, Warner (1975) indicates that a directmailing fundraising campaign costs about two dollars for every new dollar raised. Moreover, impersonal methods generally yield low response rates. Mixer (1993) argues that direct-mailing fundraising campaigns typically yield a response rate of about $1 \%$ from a random list if potential donors.

${ }^{6}$ There are dozens of commercial software available for this purpose. DonorPlus and DonorPerfect are widely-used examples.

${ }^{7}$ Here, we implicitly assume that charitable solicitations inform the potential donor that a particular charity exists and on the areas that the charity focuses on.

${ }^{8}$ As an estimation methodology, Freeman (1997) uses linear probability analysis and Schervish and Havens (1997) use OLS. Problems associated with using these methods in binary response models are well-known in the literature. See, for example, Greene (2003).
} 
for this deficiency in the literature is due to data limitations. In this paper, we employ various limited dependent variable models to investigate the effect of charitable solicitations on both the probability of giving and the amount of charitable contributions, using the most recent survey data on charitable giving in the United States. We link our data to IRS data on charitable organizations and the 2000 Census at the county level and develop appropriate instrumental variables to address the endogeneity of charitable solicitations. Our initial identifying instrument relies on the fact that public charities' fundraising efforts are generally limited to their local communities. In light of this observation, we hypothesize that as the number of charitable organizations in a county increases, residents of the county are more likely to be solicited, while their giving patterns are affected only through charitable solicitations. Hence, we first use number of public charities per capita by county as an instrument. Subsequently, as alternative intruments, we consider the fundraising expenditures spent in each county adjusted for the population and whether the respondent is a member of a social organization. We also extensively discuss the validity of our instruments.

Our empirical results confirm the hypothesis that the probability of being solicited endogenously affects both the probability of giving and the amount of money contributed. After controlling for the endogeneity, we find that people are both more likely to contribute to charity and also donate more when they are asked to. This effect is robust under different specifications and with different sets of instruments, and is also substantially larger than the effect estimated by conventional methods, which take the probability of being solicited as exogenous. Hence, our results cast doubt on the exogenous donor selection assumption of recent fundraising models.

We also examine gender differences in giving behavior. Yet in this case, due to data limitations, our efforts should be taken as informative rather than implying causal relationships. We show that the probability of being asked for a charitable gift does not differ significantly by sex, but the propensity to give and amount of charitable donations do.

Finally, we argue that some other personal characteristics are associated with the higher probability of being solicited. In particular, we find that better educated, older people with higher household incomes are more likely to be asked for charitable donations. Moreover, we find substantial evidence that race plays a key role in the selection of potential charitable donors. Hispanics are far less likely to be solicited compared with whites or blacks.

The rest of this paper is organized as follows. In the next section, we describe our data and discuss various motives for charitable giving. In section three, we set out the empirical specification 
of different models. In section four, we present the results for single equation models as a benchmark. In section five, we address the endogeneity problem of being solicited and discuss the validity of alternative instruments. Section six provides a conclusion and discussion of policy implications.

\section{Data and motives for charitable giving}

We use a unique household survey that is designed to learn about the motivations for charitable giving in the United States and contains a question on whether the respondent is personally asked to give. The Survey of Giving and Volunteering in the United States (2001) is a random-digit dial survey conducted for Independent Sector by Westat Inc. with a sample of 4,216 adults, 21 years of age and older. The survey obtains information on household giving and personal volunteering habits, various indicators of relevant motivations, household social characteristics, selected demographic descriptors, and economic factors. Weighting procedures are used to ensure that the final sample of respondents is representative of all non-instutionalized adults, 21 years of age and older. This survey, given its scale, provides the most recent and comprehensive assessment of charitable activity in United States $^{9}$.

The survey records information on giving for fifteen different charity categories ${ }^{10}$. We identify the respondent as a charitable donor if her household has given to at least one of these categories and calculate the amount of charitable contributions as the sum of money that the respondent has reported giving to each of the fifteen charity groups. Table 1 reports various personal and household characteristics that might be associated with the propensity to give and the mean amount of charitable contributions of the donors. More than $91 \%$ of the households contributed money, with an average contribution of $\$ 1,613$. Most of the donors are people with high potential earnings at their peak earning ages and with a high opportunity cost of time. They tend to be employed, well-educated, married, and have larger families. Among the charitable donors, $65 \%$ are employed,

\footnotetext{
${ }^{9}$ This is the most recent survey in the 'Giving and Volunteering in the United States' series conducted for Independent Sector. The previous versions of this survey were conducted in person by Gallup on about 2,500 households, every two years, starting from 1988. We do not use the previous versions for mainly two reasons. First, the design of the survey and the wording of the questions are considerably changed in 2001. Second, the current version of the survey obtains information on the FIPS code, which clearly identifies the county that the household resides in. Our empirical analysis relies on this information.

${ }^{10}$ The categories are religious organizations, youth development, education, health, human services, environment and animal welfare, adult recreation, arts, culture, and humanities, public or societal benefit, political organizations and campaigns, private and community foundations, international or foreign programs, giving to relatives, friends, neighbors and strangers, and other unnamed areas.
} 
$49 \%$ are married, $32 \%$ are college graduates, and they have a mean family size of 2.48 . The mean household income of donors is $\$ 54,490$, compared with $\$ 28,711$ of nondonors. Religion is also an important aspect of charitable giving. Among donors, $44 \%$ regularly attend religious services ${ }^{11}$.

Figure 1, panel A plots the propensity to give and the amount of money contributioned for different age groups. Both the propensity to give and amount of charitable donations tend to decline in the late 50's, but start to increase in early 70's. People are most likely to give in their 40 's but tend to give more in their 50's.

\subsection{Gender differences}

Are there any significant gender differences among donors? Since the survey is conducted with only one adult member of household, our data set reports only household level giving data, not male and female giving separately for married couples and couples living with a partner. Hence, due to data limitations, it is hard to answer this question precisely. Yet, following Andreoni, Brown, and Rischall (2003), we can provide at least a rough explanation by focusing on a question on the survey on who within the household is the primary decision maker in allocating money to charities. The question is worded as follows:

(Asked to all respondents) "Even though members of a household give as a unit, individual members may select certain charities or nonprofit organizations to support. Who in your household is considered most involved in deciding which organizations you give to?"

Excluding the joint decision makers and the respondents who say their spouse, partner or another household member is the primary decision maker gives us a subsample of 2,398 respondents, $36 \%$ of which are male. We report the donor and nondonor characteristics by males and females in Table 1. Male and female characteristics are virtually the same as the whole sample, but differ in magnitude. In particular, a higher percentage of male donors are Hispanic, employed, and college graduate. On the other hand, female donors are older and much more likely to attend religious services. Females contribute more to charities than males do. On average, they give \%3.09 of their incomes to charities compared with $\% 2.80$ for males.

We further investigate male and female giving patterns in Figure 1, panels B and C. Panel B presents the relationship between age and the probability of giving, by sex. Female and male giving

\footnotetext{
${ }^{11}$ Almost $52 \%$ of households give to both religious and non-religious charities, with a mean donation of $\$ 1,391$ to religions.
} 
patterns are similar for different age groups, but with some differences. Females are more likely to donate than males up to the age of 50. They are also more likely to donate in their peak earning ages, from 40 to 60. Males are more likely to donate in their 70's. However, males and females considerably differ in the amount of donations. Panel $\mathrm{C}$ shows that males donate more in all age groups except the ages from 30 to 39 , which is also consistent with the earning and giving patterns summarized in Table 1.

As we have mentioned before, we cannot precisely test the gender differences with our existing data set. Moreover, our sampling of males and females may create a selection bias if any unobservables that affect the selection of the decision maker in an household are also correlated with the giving behavior of the household. Hence, for the rest of this paper, we will mostly focus on the full sample results. For comparison purposes, we will also present empirical results for males and females separately. However, these results should be interpreted with caution.

\section{$2.2 \quad$ Tax price of giving}

Since households are allowed to itemize charitable deductions on the personal income tax, each dollar given away costs less than a dollar if the household itemizes deductions. We compute the price of giving as $1-t$ for those who itemize charitable deductions and 1 for those who do not, where $t$ is the marginal tax rate that the donor faces. We measure the marginal tax rate as the sum of the state and federal marginal tax rates, corrected for the fact that the state income tax is deductible from the federal income tax and charitable deductions were not allowed in the state income tax in some states as of $2000^{12}$. Our calculation for the tax price of giving depends on two crucial assumptions, both of which are consistent with the common practice in the literature ${ }^{13}$. First, we assume that those who itemize deductions in the federal income tax also itemize deductions in the state income tax and those who are married declare joint filing status. Second, the decision to itemize charitable deductions is exogenous to both the decision to give and the amount of charitable contributions. We further describe all of the key variables used in our empirical analysis in Appendix B.

\footnotetext{
${ }^{12}$ These states were Indiana, Massachussets, Ohio, Connecticut, Michigan, New Jersey, Illinois, and Pennsylvania.

${ }^{13}$ See, for example, Duncan (1999), and Andreoni, Brown, and Rischall (2003).
} 


\subsection{The power of asking}

The Survey of Giving and Volunteering in the United States 2001 has various questions about the ways in which people make charitable contributions. In particular, we focus on the effect of personal requests on giving behavior. The data on the variable we are primarily interested in, the probability of being asked to give, are drawn from the following question:

(Asked to all respondents) "Were you or members of your household personally asked to give money or other property to charitable organizations, including religious organizations, in 2000?"

Table 2 summarizes the answers to this question ${ }^{14}$. Even the raw numbers show the power of asking in charitable contributions. During the year prior to the survey, $58 \%$ of the respondents were asked to give at least once and more than $97 \%$ of those asked contributed money. In contrast, $42 \%$ of the respondents were not asked to give and among them, $84 \%$ contributed money. In addition, the mean amount given by the people who were asked to give is substantially more than the contribution of the people who were not asked to give. On average, people who were asked to give by a charity donated $\$ 1,929$ compared with $\$ 1,112$ for the people who were not solicited. Alternatively, people who were solicited donated \%3.45 of their incomes on average compared with \%2.67 for the people who were not solicited. In Table 2, we also report the responses of males and females separately. Females are more likely to be asked and more likely to accede to donation requests. Females also give more when they were asked to. On average, when solicited, females donated \%3.32 of their income on average compared with \%3.12 for females.

Our unique data set also provides some evidence in support of our underlying hypothesis, that most of the fundraising activity is well-planned and hence, the selection of donors for charitable solicitations is non-random. For example, only $8.7 \%$ of the respondents said that they or a member of their household contributed money by responding to a TV or radio request, maybe the only fundraising technique for which solicitations are random. More strikingly, among those people, $65 \%$ of the $8.7 \%$ said that being asked to give is the primary reason for why they or a member of their household made a charitable contribution. Fundraising through street collections can also be thought of as an example of random solicitations. However, in contrast to radio or TV solicitations, a fundraiser can choose the location, and hence may target a specific population. Simple tabulations

\footnotetext{
${ }^{14}$ Although the request to give could have been made by mail, by phone or face to face, there are at least two reasons to believe that most of the requests have been made face to face. First, face to face solicitations are known to be a more effective way of fundraising than mail or phone solicitations. Second, people are more likely to remember and therefore report face to face requests than mail or phone solicitations.
} 
from our data set show that $34 \%$ of the respondents made a charitable contribution through street collection but among them, $68 \%$ reported that being asked to give was the primary reason for their contribution.

Tabulations from the data also show that when it comes to charitable giving, being asked to give is a more important reason than tax deduction incentives or fulfilling religious obligations. Finally, our tabulations are also in line with those of Freeman (1997), who argues that the same pattern is observed in the previous versions of this survey, in a telephone survey of volunteering and charitable giving among Boston residents (Freeman, 1993), and in a Rockefeller Brothers study of charitable contributions (Rockefeller Brothers Fund, 1986, p. 22).

\section{The effect of donation requests on charitable giving}

Recent formal models on fundraising rarely consider the problem of how charitable solicitations may affect the giving behavior of potential donors. Here, we use a simplified version of the model developed in Andreoni and Payne (2003) to discuss how asking may increase both the propensity to give and the amount of charitable contributions. Consider a simple case in which there is only one type of charity (a pure public good) that people can contribute to. Let individual $i$ 's contribution to the public good be $d_{i}$, where $d_{i} \geq 0$ for all $i$, and let $\theta_{i}$ be the probability that individual $i$ is solicited by the charity. Let the cost of soliciting individual $i$ be $c_{i}\left(\theta_{i}\right)$. We assume that the marginal cost of fundraising is increasing in $\theta, \partial c / \partial \theta>0$. Finally let $G$ be sum of government grants received by the charity and revenues raised without any fundraising practices. We define the total level of charitable services as

$$
D=G+\sum_{i=1}^{n}\left[d_{i}\left(\theta_{i}\right)-c_{i}\left(\theta_{i}\right)\right]
$$

Equation (1) immediately implies that fundraising has two distinct effects. On the one hand, it is costly to solicit donors since higher $\theta$ costs more in fundraising expenditures. On the other hand, it turns nondonors to donors and increases the amount of donations by the existing donors. Therefore, a fundraiser strategically targets and solicits a donor only if the cost of asking is less than or equal to the amount of donation he expects to receive. In selecting the target donors, a fundraiser relies on quantifiable information sources. Hence, $\theta_{i}$ is a function of both the personal and demographic characteristics of donor $i$, which are observable to the econometrician, and unobservable charac- 
teristics, such as previous donations of the donor to the charity or the ideology ${ }^{15}$ of the donor. Let $X_{i}$ donate the observable characteristics of the donor $i$, and $u_{i}$ represent the unobservable characteristics. Then, we can define the probability of being solicited as $\theta_{i}=\theta_{i}\left(X_{i}, u_{i}\right)$.

Given the solicitations received, individuals solve a standard utility maximization problem. Let $x_{i}$ be donor $i$ 's consumption of private goods. Then, we assume the preferences of the donor can be represented as $U_{i}=u_{i}\left(x_{i}, d_{i}\left(\theta_{i}\right)\right)$. Then, each donor maximizes utility subject to the budget constraint $y_{i}+p_{i} d_{i}=m_{i}$, where $p_{i}$ is the tax price of giving and $m_{i}$ is the income of the donor. Hence, the equilibrium level of donations can be defined as $d_{i}=d_{i}\left(\theta_{i}, m_{i}, p_{i}\right)$.

\subsection{Empirical Models}

In this section, we consider two limited dependent variable models, in which the dependent variables are the probability of giving and the amount of charitable donations. First, we consider a probit model with an endogenous binary variable of the probability of being solicited. For donor $i$, let $d_{i}^{*}$ describe the net benefit from giving given by the following underlying model:

$$
d_{i}^{*}=\beta_{1}^{\prime} X_{1 i}+\gamma \theta_{i}+u_{1 i}
$$

where $X_{1 i}$ is a covariate vector of income, the tax price of giving, and other observable characteristics of the donor and $u_{1 i}$ is a normally distributed random error with zero mean and unit variance. We do not observe the net benefit from giving, but we observe whether individual $i$ donated or not, which is given as

$$
d_{i}=\mathbf{1}\left\{\beta_{1}^{\prime} X_{1 i}+\gamma \theta_{i}+u_{1 i} \geq 0\right\}
$$

where $\mathbf{1}($.$) denotes the indicator function. If fundraisers randomly select individuals to solicit,$ then, being solicited is exogenous and the parameters of equation (3) can be estimated directly by specifying a distribution for $u_{1 i}$. However, if being solicited is endogenous, failing to take into this into account results in biased parameter estimates.

In order to address the endogeneity problem, let $\theta_{i}^{*}$ be the probability that individual $i$ is solicited by a charity. The reduced form behavioral model is defined as

$$
\theta_{i}^{*}=\beta_{2}^{\prime} X_{2 i}+u_{2 i}
$$

\footnotetext{
${ }^{15}$ By 'ideology', we mean the different varieties of services that the charity can provide and different charitable tastes of donors. In this context, Rose-Ackerman (1982) uses the word 'ideology', Economides and Rose-Ackerman use (1993) 'type', and Andreoni and Payne (2003) use 'quality'. We follow Rose-Ackerman (1982).
} 
where $X_{2 i}$ is a vector of covariates and $u_{2 i}$ is a normally distributed random error with zero mean unit variance. Again, we do not observe $\theta_{i}^{*}$ but rather a binary variable $\theta_{i}$, which is given as

$$
\theta_{i}=\mathbf{1}\left\{\beta_{2}^{\prime} X_{2 i}+u_{2 i} \geq 0\right\}
$$

Since, both dependent variables are dichotomous, there are four possible states of the world $\left(\theta_{i}=\right.$ 1 or $\theta_{i}=0$ and $d_{i}=1$ or $\left.d_{i}=0\right)$. We assume that the error terms are independently and identically distributed as bivariate normal with $E\left[u_{1 i}\right]=E\left[u_{2 i}\right]=0, \operatorname{var}\left[u_{1 i}\right]=\operatorname{var}\left[u_{2 i}\right]=1$, and $\operatorname{cov}\left[u_{1 i}, u_{2 i}\right]=\rho$. Then, following Evans and Schwab (1995) and Wooldridge (2002), the likelihood function corresponding to this set of events can be estimated as a bivariate probit. If $\rho \neq 0$, then $u_{1 i}$ and $u_{2 i}$ are correlated and running separate probit regressions for the equations (3) and (5) yields inconsistent estimates for the parameter vectors. We further discuss the derivation of the log-likelihood function for this model in Appendix A.

Following Maddala (1983), it is widely believed in the literature that in the joint estimation of (3) and (5), parameter vectors are not identified in the absence of exclusionary restrictions, that is, if $X_{1 i}$ includes all the variables in $X_{2 i}$. However, Wilde (2000) argues that Maddala's statement is only valid if $X_{1 i}$ and $X_{2 i}$ are both constants and shows that the model is identified as soon as both equations have a varying exogenous regressor. Monfardini and Radice (2006) also state that identification of this model does not require any additional instruments in $X_{2 i}$, but note that in the absence of exclusionary restrictions, identification heavily relies on the functional form. Therefore, estimation with additional instruments might yield parameter estimates that are more robust to distributional misspecification. Hence, we rely on appropriate instruments in our analysis, but for comparison purposes, we also report the parameter estimates of the model, which is identified thorough the functional form assumptions.

Our second empirical model investigates the relationship between the probability of being asked and the amount of charitable donations. This analysis is motivated by a well-known fundraising technique, that is, fundraisers often ask for a certain amount when soliciting donations. In general, in order to receive the highest possible donation, the fundraiser proposes an amount, which is higher than what he expects to receive, and slightly reduces it until the donor accepts the proposed amount and makes the donation. Therefore, we hypothesize that being asked by a charity not only increases the probability of giving but also the amount of charitable donations. Since some people do not donate any amount, to formally test this hypothesis, we estimate a tobit model with an 
endogenous probability of being solicited ${ }^{16}$. Let $\bar{d}$ be the amount of donation. Then, our joint system is defined as:

$$
\begin{gathered}
\bar{d}_{i}^{*}=\alpha_{1}^{\prime} X_{1 i}+\eta \theta_{i}+\varepsilon_{1 i} \\
\theta_{i}^{*}=\alpha_{2}^{\prime} X_{2 i}+\varepsilon_{2 i}
\end{gathered}
$$

where $\bar{d}_{i}$ and $\theta_{i}$ are observed according to the following rule:

$$
\begin{gathered}
\bar{d}_{i}=\max \left\{\left(\alpha_{1}^{\prime} X_{1 i}+\eta \theta_{i}+\varepsilon_{1 i}\right), 0\right\} \\
\theta_{i}=\mathbf{1}\left\{\alpha_{2}^{\prime} X_{2 i}+\varepsilon_{2 i} \geq 0\right\} .
\end{gathered}
$$

The error terms are assumed to be independently and identically distributed as bivariate normal with $E\left[\varepsilon_{1 i}\right]=E\left[\varepsilon_{2 i}\right]=0, \operatorname{var}\left[\varepsilon_{1 i}\right]=\sigma^{2}$ and $\operatorname{var}\left[\varepsilon_{2 i}\right]=1$, and $\operatorname{cov}\left[\varepsilon_{1 i}, \varepsilon_{2 i}\right]=\varphi \sigma$. If $\varphi \neq 0$, then $\varepsilon_{1 i}$ and $\varepsilon_{2 i}$ are correlated and separate probit and tobit estimation for the equations in (7) yields inconsistent estimates for the parameter vectors. Similar to the probit model with binary endogenous variable, we use the maximum likelihood (ML) methodology to estimate this model. We present the log-likelihood functions corresponding to this model in Appendix A.

\section{Univariate models}

\subsection{Univariate probit models}

As a benchmark, we first assume that $\rho=0$, and estimate two separate probits for the equations (3) and (5). In Table 3, we consider the probability of giving as a binary outcome and report the coefficient estimates and the marginal effects ${ }^{17}$ of the explanatory variables. The first two columns of Table 3 record the benchmark results for the whole sample. In the first column, the highly significant and positive coefficient of the asked to give dummy implies that people who are asked to give are much more likely to donate than those who are not asked to. Holding other variables constant, being asked by a charity increases the propensity to give by more than $7 \%$. The estimated coefficients of the other variables are consistent with the literature in this area. Employed, white,

\footnotetext{
${ }^{16}$ This type of model is classified as corner solution outcome in Wooldridge (2002).

${ }^{17}$ For binary variables, marginal effects show the effect of a discrete change of the variable on the dependent variable holding other variables constant. For continous variables, marginal effects are calculated at the mean and show the effect of a percentage point change of that variable on the dependent variable. It is also possible to compute marginal effects for representative donors. For example, for the representative donor, who is a 45 year old white male, has a high-school diploma, has an household income of $\$ 42,000$, lives in a three person household, regularly attends religious services, itemizes charitable deductions, faces a $30 \%$ marginal tax rate, and is not asked to give, the marginal effect of being solicited is $3.14 \%$.
} 
better educated individuals with higher household incomes and larger families are more likely to donate. Race does not significantly affect the giving behavior but religion does. Furthermore, the coefficient on the tax price of giving is negative and significant. The marginal effects presented in the second column imply that the impact of being asked on charitable giving is larger than the impact of any other variable. In particular, its impact is more than two times larger than being a college graduate and more than three times larger than the impact of household income.

In Table 3, we also report the average treatment effect (ATE) and average treatment effect on the treated (ATT) of the asked to give dummy on the propensity to give. Let $d_{i 1}$ be the outcome if an individual is asked to give and $d_{i 0}$ be the outcome if she is not asked to. We define ATE as $E\left(d_{i 1}-d_{i 0} \mid \theta_{i}\right)$. For a random individual, this corresponds to the average difference between the probability that an individual would donate if she is asked to give and the probability that she would donate if she is not asked to. Let $n$ be the sample size and $\Phi($.$) be the standard normal$ cumulative distribution, then the ATE can be computed for the probit model as

$$
\widehat{\operatorname{ATE}}_{(p)}=\frac{1}{n} \sum_{i=1}^{n}\left[\Phi\left(\widehat{\beta}_{1}^{\prime} X_{1 i}+\widehat{\gamma}\right)-\Phi\left(\widehat{\beta}_{1}^{\prime} X_{1 i}\right)\right] .
$$

In a similar manner, we define $\mathrm{ATT}$ as $E\left(d_{i 1}-d_{i 0} \mid \theta_{i}=1\right)$. This is the average effect of being asked on those who actually are asked to give and can be computed as

$$
\widehat{\operatorname{ATT}}_{(p)}=\left(\sum_{i=1}^{n} \theta_{i}\right)^{-1} \sum_{i=1}^{n} \theta_{i}\left[\Phi\left(\widehat{\beta}_{1}^{\prime} X_{1 i}+\widehat{\gamma}\right)-\Phi\left(\widehat{\beta}_{1}^{\prime} X_{1 i}\right)\right] .
$$

The ATE of the asked to give dummy is $8.2 \%$, which is slightly higher than its marginal effect. The coefficient on ATT suggests that solicitations increase the probability of giving by almost $7 \%$ for those who actually are solicited. The standard errors computed by the delta method suggests that these effects are highly significant.

In the remaining columns of Table 3, we examine the same empirical model separately for males and females. Comparing male and female models, we find that giving behavior of males and females are significantly different. The hypothesis that their behavior is identical ${ }^{18}$ can be rejected at the $10 \%$ level of significance, i.e., $\chi_{(17)}^{2}=25.01, p-$ value $=0.094$. Both males and females are more likely to donate when they are asked to. Holding other variables constant, the probability of giving increases by $7.2 \%$ for males and $6.1 \%$ for females in response to being solicited. Yet, this

\footnotetext{
${ }^{18}$ This is the joint test of the equality of the coefficients in the male and female probability of giving equations.
} 
difference between males and females is insignificant. The equality of coefficients on the asked to give dummy across male and female equations cannot be rejected at conventional significance levels, i.e., $\chi_{(1)}^{2}=0.35, p-$ value $=0.552$. The coefficient on the tax price of giving is significant and negative for both males and females. For both males and females, education and attending religious services are positively associated with the propensity to give. The estimated ATE coefficients imply that being asked by a charity increases the probability of giving by $7 \%$ for a randomly selected male and $6.4 \%$ for randomly selected female. Finally, ATT coefficients imply that for those who are asked to give, being asked by a charity increases the probability of giving by $6.1 \%$ for males and $5.2 \%$ for females.

In Table 4, we consider probability of being asked as a binary outcome and investigate the factors that differentiate between those who are asked to give and those who are not. We find that better educated, older individuals with higher household earnings are more likely to be asked for charitable donations. Furthermore, white people and people who regularly attend religious services are more likely to be asked for charitable contributions, whereas Hispanics are far less likely to be asked. The marginal effect of the Hispanic dummy on the probability of being solicited suggests that Hispanics are almost $10 \%$ less likely to be solicited, whereas white people are almost $11 \%$ more likely to be asked, keeping other variables constant. This shows that race plays an important role in the selection of charitable donors.

Comparing male and female equations, we cannot reject the hypothesis that the probability of being solicited significantly differs by $\operatorname{sex}^{19}\left(\chi_{(16)}^{2}=20.82, p-\right.$ value $\left.=0.186\right)$. As in full sample estimates, higher household income is associated with the higher probability of being solicited, both for male and female donors. A one percentage point increase in household income increases the probability of being solicited by more than $10 \%$ for male donors and almost $8 \%$ for female donors. For both males and females, being white and employed considerably increases the probability of being solicited. Finally, better educated females are more likely to be solicited. For example, a female college graduate is $11 \%$ more likely to be solicited than a female high school graduate and moreover, an additional level of education increases the probability of being solicited by about $6 \%$. A similar effect of education on the probability of receiving a donation request is observed for male donors. For males however, the marginal effects on the education dummies are insignificant except

\footnotetext{
${ }^{19}$ This is the joint test of the equality of the coefficients in the male and female probability of being solicited equations.
} 
for the coefficient of the graduate school dummy.

\subsection{Univariate tobit models}

In this section, we investigate the relationship between being solicited and the amount of charitable donations assuming that the probability of receiving a donation request is exogenous, i.e., $\varphi=0$. Given the censoring of the amount of charitable donations at zero, our estimation strategy is tobit analysis. Our dependent variable is the natural logarithm of (1+ total charitable contributions). Employing a tobit model and using the natural logarithm transformation of the charitable contributions are widely used in the literature, but we also add the constant 1 so that the transformed variable still takes the value zero if the original amount of donation is zero. We report the parameter estimates and the associated marginal effects ${ }^{20}$ of this model in Table 5 . The coefficient of the asked to give dummy is highly significant and positive, which implies that being asked for charitable donations not only increases the probability of giving but also increases the amount of charitable donations. Since the latent variable $\bar{d}_{i}^{*}$ is not of interest, we need to focus on the marginal effects of the independent variables on total charitable contributions. Holding other variables constant, people who are solicited give almost twice as much as than those who are not solicited. As in the probit models, we report positive and significant coefficients and marginal effects for education dummies and household income. Similarly, white people with larger families tend to donate more, and the coefficient on the tax price of giving is significantly negative. In contrast to the estimates of the probit model, in the tobit model the marginal effects of education dummies and the tax price of giving are higher than the marginal effect of being solicited. Hence, when it comes to donation amount, our univariate tobit models show that tax incentives and educational attainment are more important factors than being solicited.

In Table 5, we also report the ATE and ATT of being solicited on the donation amount. Following Greene (1999) and Angrist (2001), we compute the ATE for the tobit model as

$$
\widehat{\operatorname{ATE}}_{(t)}=\frac{1}{n} \widehat{\eta} \sum_{i=1}^{n}\left[\Phi\left(\widehat{\alpha}_{1}^{\prime} X_{1 i}+\widehat{\eta} \theta_{i}\right)\right] .
$$

Similar to univariate probit model, the ATT can therefore be approximated as

$$
\widehat{\operatorname{ATT}}_{(t)}=\left(\sum_{i=1}^{n} \theta_{i}\right)^{-1} \widehat{\eta} \sum_{i=1}^{n} \theta_{i}\left[\Phi\left(\widehat{\alpha}_{1}^{\prime} X_{1 i}+\widehat{\eta} \theta_{i}\right)\right] .
$$

\footnotetext{
${ }^{20}$ The marginal effects are computed for the expected value of the dependent variable conditional on being uncensored.
} 
For the full sample, the ATE and ATT of being solicited on the amount of charitable donations (in natural logarithm points) are $105 \%$ and $104 \%^{21}$.

Table 5 also records the coefficients and marginal effects for the tobit model for male and female donors separately. Both male and female donors are highly responsive to requests to give. Holding other variables constant, a charitable solicitation increases the amount of donation by $94 \%$ for males and $93 \%$ for females. The computed ATE and ATT coefficients are slightly larger than the marginal effects. The estimated ATE coefficients imply that being asked by a charity increases the donation amount by $107 \%$ for a randomly selected male and $99 \%$ for a randomly selected female. On the other hand, the ATT coefficients imply that for those who are asked to give, being asked by a charity increases the probability of giving by $106 \%$ for males and $98 \%$ for females. We cannot reject the hypothesis that the amount of charitable donations differs by sex, i.e. $\chi_{(17)}^{2}=20.74$, $p$-value $=0.238$. Moreover, we cannot reject the equality of the coefficients on the asked to give dummy across male and female equations, i.e., $\chi_{(1)}^{2}=0.14, p-$ value $=0.709$. The effects of the other independent variables on male and female equations follow the same pattern as in the whole sample. For both males and females, education, household income, family size, and religion are positively associated and the tax price of giving is negatively associated with charitable contributions. Family size and age have a positive and significant effect on the amount of donations only for males, however.

\subsection{Robustness checks for univariate models}

Table 6 shows the results of the sensitivity tests performed to determine whether our estimates are subject to omitted variables bias, and hence have overstated the effect of charitable solicitations. We first include three additional dummies to our model capturing whether the respondent owns her residence, whether she was born in USA, and whether she has voted in the 2000 presidential election. We expect that people who own their primary residence are more integrated into their

\footnotetext{
${ }^{21}$ Instead of using a tobit model, Schervish and Havens (1997) employ OLS to estimate the effect of charitable solicitations on the donation amounts. For comparison purposes, we run two OLS models using the natural logarithm of the total amount of charitable contributions and donations as a percentage of household income as dependent variables. The results are similar to that of Schervish and Havens (1997). In the first model, the coefficient of asked to give dummy is 0.300 with a standard error of 0.138 , whereas the second model yields a coefficient estimate of 0.864 with a standard error of 0.138 . This estimates are comparable to the ATE estimated by the tobit model and imply a smaller effect of being solicited on the amount of charitable donations.
} 
community and hence, more likely to give. Similarly, we expect that people who were born in America and vote in the elections care much about the needy, and are therefore more likely to give to charities. Not surprisingly, although not reported, the estimated coefficients on these variables were positive, and statistically significant except for the standard error of born in the USA dummy, which was insignificant in all specifications. Including these extra variables reduces the ATE, and ATT of the asked to give dummy by $0.7 \%$ in the probit model and about $8 \%$ in the tobit model. For males and females, including these variables reduces the estimated effect by approximately $1 \%$ in the probit model and approximately $15 \%$ in the tobit model. In all cases, however the effect of donation requests on the probability of giving and amount of charitable contributions remains considerably large and highly significant.

In our empirical models, we implicitly assume that people do not care how much others would donate. In contrast to this 'pure warm glow' model ${ }^{22}$, we can alternatively consider a 'public goods' model and add charitable gifts of others as an independent variable to our model as in Duncan (1999). In order the construct the data for the charitable gifts of others, we use the Federal Information Processing Standard (FIPS) code, which is assigned to each household in the data and identifies the county ${ }^{23}$ that the household resides in. For each household, we measure the gifts of others as the natural logarithm of the total contributions in a county, excluding the current household. Including this variable to our model reduces our estimate of the ATE by only around $0.2 \%$ and the ATT by $1.6 \%$ in the probit model and the ATE by $4.4 \%$ and the ATT by around $11 \%$ in the tobit model. Interestingly, when we estimate our single equation models for only males, including the total contributions by others to our models increases the ATE by around $0.9 \%$ for the probit model and $11 \%$ for the tobit model. For females, the effect of the extra variable on the ATE and ATT is virtually the same as in the full sample estimates, but differs in magnitude. Including the gift of others to our model decreases ATE of being asked to give from $6.4 \%$ to $6.3 \%$ in the univariate probit model and $99 \%$ to $89 \%$ in the univariate tobit model. We should also note that the coefficient estimate of the gifts of others was insignificant in all the models considered; hence we conclude that including this variable does not significantly affect our original estimates.

Since different states have different economic environments and in particular different tax incentives for charitable giving, including the state effects may considerably alter our original estimates. The reported estimates for the model including the state effects imply that this is not the case.

\footnotetext{
${ }^{22}$ The theory of warm glow giving is analyzed in Anreoni (1989, 1990).

${ }^{23}$ U.S. Census Bureau lists 3,141 counties averaging 63 counties per state.
} 
As in the previous models, including the state effects only slightly affects our estimates. For the full sample, including the state effects in our model increases our estimates by around $0.4 \%$ for the probit model and $2 \%$ for the tobit model. For males and females, including the state effects increases our estimates around $1 \%$ for the probit and tobit models.

Finally, we estimate one large model including the extra dummy variables, gifts of others, and state effects. We find that this model predicts slightly lower estimates for the ATE and ATT of asked to give dummy for the full sample and slightly higher estimates when we estimate our models for males and females separately. To sum up, we can confidently say that the ATE of being solicited on the propensity to give is more than $7 \%$, and the ATT is more than $4.5 \%$ for the univariate probit models, whereas the ATE of being solicited on the amount of charitable donations is at least $79 \%$ and the ATT is more than $76 \%$ for the univariate tobit models.

\section{Models with endogenous probability of being solicited}

\subsection{Bivariate probit models}

Up to now, all the single equation probit and tobit models treat the probability of being solicited as exogenous. As we have discussed before, many unobservable characteristics of donors such as ideology, previous donations to a particular charity, peer effects, group membership, or social status that would be correlated the propensity to give and the amount of charitable contributions would also be correlated with the probability of being solicited. In this section, we address the possible endogeneity of the asked to give dummy in equation (3). For this purpose, we estimate bivariate probit models under different specifications. Our models are properly identified if at least one variable that is correlated with the probability of being solicited is not correlated with the propensity to give. For comparison purposes, we also estimate benchmark bivariate probit models without considering any additional instruments by relying on functional form assumptions.

Initially, we use the number of public charities in a each county adjusted for population (PCP) as an instrument. The FIPS code assigned to each household in our data enables us to link our survey to IRS data on charitable organizations, which is available through the National Center for Charitable Statistics compiled by the Urban Institute, and the 2000 Census, which is available through the U.S. Census Bureau. Both of the data sources obtain information at the county level. The IRS data record information on both public and private charities, both of which are required 
to file a tax return unless they report gross receipts of less than 25,000 or they are a religious $\operatorname{organization}^{24}$. In our analysis, we particularly focus on the public charities for two reasons. First, in contrast to private charities that are primarily grantmaking organizations and generate their revenues mostly from government grants, public charities rely mostly on private donations. Second, public charities constitute $75 \%$ of all charitable organizations and include most of the nonprofit organizations involved in the arts, health care, education, human services, and community service, as well as many others. Instead of fundraising at the national level, these charities generally focus on their local communities and solicit donors who reside within that community. Using IRS data, we calculate the total number of public charities for each county in the survey year 2000. The 2000 Census contains the population of each county for the survey year. Hence, for each household, we compute PCP as the total number of public charities located in the county of the household divided by the population of the county. We expect that as the number of charitable organizations per capita in a county increases, people who live in that particular county would be more likely to be solicited for charitable contributions. Subsequently, we consider alternative instruments and discuss the validity of those variables as appropriate instruments below.

In Table 7, we report the ML estimates of the base bivariate probit models using PCP as an instrument. The estimate of the correlation coefficient $\rho$ is negative and statistically significant. We reject the null hypothesis that $\rho=0$ at $1 \%$ level using a simple Wald test ${ }^{25}$. Therefore, we can confidently say that the error terms of the equations (3) and (5) are correlated and being solicited endogenously affects the propensity to give. Since our estimate of $\rho$ is negative, we expect that our single equation probit models underestimate the true effect of being solicited. This is precisely the case. In Table 7, we report that the ATE and ATT of being asked by a charity on the propensity to give are $31 \%$ and $16 \%$, respectively, both of which are substantially larger than the effect estimated by the single equation models ${ }^{26}$. One likely reason for this result is the attenuation bias due to the measurement error in an independent variable. In particular, the survey literature generally

\footnotetext{
${ }^{24}$ This data come from the tax returns filed by IRS section 501(c)(3) organizations for year 2000 and are available at the Urban Institute's website at http://www.urban.org/.

${ }^{25}$ Alternatively, we can use a likelihood ratio (LR) test, which is computed as $-2\left(L_{d}+L_{\theta}-L_{B}\right)$, where $L_{d}+L_{\theta}$ is the sum of the log-likelihood function values of separately estimated probits of probability of giving and probability of being solicited equations and $L_{B}$ is the $\log$-likelihood function value of the bivariate probit model. The LR test, which is asymptotically distributed as $\chi_{(1)}^{2}$ under the null hypothesis, also rejects the null hypothesis at $1 \%$ level $\left(\chi_{(1)}^{2}=34.06, p-\right.$ value $\left.=0.000\right)$.

${ }^{26}$ Equations (8) and (9) are used to compute the ATE and ATT in bivariate probit models.
} 
reports that respondents' answers on attitudinal questions are subject to measurement error. Our bivariate probit models estimated by appropriate instruments both address the endogeneity problem and correct for the measurement error.

Household income and education still have a positive effect on the probability of giving in the base bivariate probit model, but their impact is much smaller once the endogeneity is controlled for. As in the simple probit model, those who are employed and white, and regularly attend religious services are much more likely to give, but the effects of these variables are smaller in the bivariate probit model. The effect of family size on the probability of giving is positive and almost the same in the univariate probit and bivariate probit models. Finally, the tax price of giving has a significant and negative effect on the propensity to give, but its effect is smaller than in the single equation probit model. In our bivariate probit model, the coefficient on PCP is highly significant and positive as expected. As in the probit model, those who are better educated, older, have higher household incomes, and who regularly attend religious services are more likely to be solicited. Race remains an important determinant of the probability of being solicited. Whites are more likely to be asked for charitable donations, whereas Hispanics are less likely to be asked. Although not reported $^{27}$, the marginal effects of these variables on the probability of being solicited is almost the same in the bivariate probit and the univariate probit models.

Table 7 reports the estimates of our bivariate probit model for males and females. Our estimate of $\rho$ is significant and negative in both the female and male bivariate probit models. However, we reject the null hypothesis that $\rho=0$ at conventional significance levels only for females. For males, the coefficient on PCP in the bivariate probit model is negative and highly insignificant suggesting that our proposed instrument fails to provide enough variation across households probably due to the small sample size of this group. However, the coefficient on the asked to give dummy is significantly higher than its single equation probit estimate in both male and female bivariate probit models. The ATT of being solicited on the propensity to give is $26 \%$ for males and $11 \%$ for females in bivariate probit models. As we observe for the full sample, controlling the endogeneity problem suppresses the magnitude of other independent variables in both models. Moreover, consistent with the results of single equation probit models, household income, age, and education are the primary determinants of the probability of being solicited both for males and females. Although

\footnotetext{
${ }^{27}$ The marginal effect of being solicited on the propensity to give can be computed for the joint positive outcomes. For example, for the full sample, we compute the marginal effect of being solicited between $23 \%$ and $30 \%$ under alternative bivariate probit models.
} 
our estimates for the male bivariate model are imprecise, for comparison purposes, we also test gender differences in giving behavior using the bivariate probit estimates. Our results are in line with the single equation probit models. We reject the hypothesis that males and females are equally likely to give at the $5 \%$ significance level $\left(\chi_{(17)}^{2}=32.68, p-\right.$ value $\left.=0.012\right)$. We cannot reject the hypothesis that the probability of being solicited differs by sex $\left(\chi_{(17)}^{2}=21.50, p-\right.$ value $\left.=0.205\right)$ and finally, we cannot reject the hypothesis that charitable solicitations have the same effect on males' and females' giving decisions $\left(\chi_{(1)}^{2}=2.38, p-\right.$ value $\left.=0.123\right)$.

In Table 8, we further check the robustness of our results in the bivariate probit models using the same additional independent variables that we employ in the single equation models. For the full sample, we reject the null hypothesis that $\rho=0$ at $1 \%$ significance levels for all specifications. In the first specification, we rely on the functional form assumptions and run a bivariate probit model without any additional instruments. This model yields similar results as the base model that is estimated with PCP as the instrumental variable. In this model, the ATE and ATT of being asked by a charity on the propensity to give is $28 \%$, and $16 \%$.

In the second specification, we record the same estimates for the base model that we have presented in Table 7. Angrist $(1991,2001)$ shows that in certain cases, ignoring the fact that the dependent variable is binary and estimating a two stage least squares (2SLS) with instrumental variables results a coefficient estimate on the asked to give dummy that is similar in magnitude to its estimated ATE in a bivariate probit model ${ }^{28}$. For all bivariate probit models estimated with the instrumental variable, a comparison of the ATE of the asked to give dummy on the propensity to give and the 2SLS estimate reported in the last column of Table 8 illustrates this result. We later use this result in addressing the validity of our instruments.

The third specification adds three additional dummy variables that we have used in the univariate probit model to the giving equation of the bivariate probit model. Including these variables to our model reduces the ATE and ATT of being asked to give on the probability of giving only by $0.1 \%$ and $1.9 \%$, respectively. The effect of charitable solicitations on giving behavior remains positive, highly significant and substantially larger than its effect estimated by the single equation probit model.

In the fourth specification, we include the others' charitable contributions as an independent variable to our giving equation. The ATE of being solicited on the propensity to give increases by

\footnotetext{
${ }^{28}$ Note that, in 2SLS models, the ATE equals the ATT.
} 
$1.5 \%$ relative to the base model and the estimate of the ATT decreases by only $1.4 \%$.

In the fifth specification, the estimated effect of the asked to give dummy on the probability of giving imply that including the state effects in our bivariate probit model only slightly reduces the ATE of this variable. Interestingly, the ATT of being solicited on the propensity to give increases by $0.8 \%$ compared with the base model. The coefficient on the asked to give dummy in the 2SLS model suggests a considerably lower ATE estimate than in the bivariate probit model. This effect is insignificant and imprecise, however.

In specification six, we run a bivariate probit model including the extra dummy variables, state effects, and charitable contributions of others. This large model yields lower estimated effects of charitable solicitations on the propensity to give. The ATE, and ATT estimates decreases by $3 \%$ and $1.5 \%$ relative to the base model.

In the remaining specifications, we estimate these bivariate probit models for males and females separately. For males, we reject the null hypothesis that $\rho=0$ at conventional levels under two specifications, on with the three additional dummies and the other with all additional explanatory variables in our giving equation. The coefficient on the asked to give dummy in all specifications is negative and insignificant and hence incomparable with the ATE estimated by the bivariate probit models. Except for the model with state effects, the estimated effect of being solicited on the probability of giving is positive and significant in all the bivariate probit models and considerably larger than its effect estimated by the single equation probit models. The estimated ATE of charitable solicitations on the propensity to give is imprecisely high and differs between $40 \%$ and $49 \%$ under different specifications.

For females, we reject the null hypothesis that $\rho=0$ for all specifications, except for the base model estimated without any additional instruments. As in the full sample estimates, the ATE and ATT of the asked to give dummy on the propensity to give is larger than the univariate probit estimates in all specifications. The 2SLS estimates are positive and similar to ATE estimates generated by the bivariate probit models. The additional variables considered in different specifications have little impact on our basic conclusions in the base bivariate probit model, which is estimated using PCP as an instrument. Including extra dummies or state effects only slightly reduces the ATE of being asked to give. However, adding the charitable contributions of others leads to larger ATE and ATT estimates than in the base model. Under different specifications, the estimated ATT of being asked to give on the probability of giving differs between $11 \%$ and $19 \%$. 


\subsection{Tobit models with endogenous probability of being solicited}

As in the bivariate probit models, our tobit models with an endogenous probability of being solicited (hereafter, endogenous tobit models) are properly identified if at least one variable that is correlated with the probability of being solicited is not correlated with the error term of the amount of charitable donations equation. However, for comparison purposes, we also estimate endogenous tobit models by relying solely on the functional form, i.e., without any additional instruments. In our initial estimations, we use the same instrumental variable (PCP) as we have used in the estimation of the bivariate probit model. We will consider alternative instruments and discuss the credibility of our instruments in the next section.

In Table 9, we report the ML estimates of the endogenous tobit models for the full sample and separately for males and females. For the full sample, the estimate of the correlation coefficient $\varphi$ is negative and statistically significant. Using a simple Wald test, we reject the null hypothesis that $\varphi=0$ at $1 \%$ level. Moreover, the coefficient on PCP is significantly positive. Therefore, estimating a single equation tobit model yields inconsistent coefficients for the parameter vectors. Since our estimate of $\varphi$ is negative, single equation tobit models underestimate the true effect of being solicited on the amount of charitable donations. As expected, the estimated coefficient on the asked to give dummy is substantially larger than the single equation estimates. After controlling for the endogeneity, the estimated ATE coefficient implies that being asked by a charity increases the donation amount by $334 \%$ in natural logarithm points for a randomly selected individual. This amount is almost three times larger than the ATE estimate in the base univariate tobit model. Similarly, in our endogenous tobit model, the ATT of being solicited on the amount of donations $(227 \%)$ is almost two times larger than the ATT estimate of in single equation tobit model.

As in the univariate tobit model, household income, education, and attending to religious services are positively associated, and the tax price of giving is negatively associated with the amount of charitable contributions. Family size and being white still positively affect the donation amount, yet this effect is insignificant once the endogeneity is controlled for. People who are better educated, older, and have higher household incomes are more likely to be solicited. Finally, as in the bivariate probit model, whites and blacks are much more likely to be solicited when compared with Hispanics.

For comparison purposes, the remaining columns of Table 9 report the estimates of the endogenous tobit models for males and females. The estimate of $\varphi$ is significant in both the male and 
female endogenous tobit models. For females, the coefficient on PCP is significantly positive and we also reject the null hypothesis that $\varphi=0$ at conventional significance levels. As in the full sample model, the female endogenous tobit model yields much larger coefficient, ATE and ATT estimates of being solicited on the donation amount relative to the single equation tobit estimates. After controlling for the endogeneity, the ATT estimate suggests that charitable solicitations increase female's donations by $232 \%$.

For males, our estimates are insignificant and imprecise. The coefficient on the asked to give dummy is negative and insignificant. Moreover, although the coefficient of PCP is positive as expected, it is insignificant at 5\% significance level. Education remains the most important determinant of the probability of being solicited in both the male and female equations. Males with higher incomes are much more likely to be solicited, whereas income is not a significant determinant of the probability of being solicited for females. As in the full sample results, white and black females are much more likely to be solicited than are Hispanic females. Finally, although our estimates for the male endogenous tobit model is insignificant and imprecise, we conduct the same tests that we have conducted in the univariate and the bivariate models, primarily for comparison purposes. Using endogenous tobit estimates for males and females, we reject the hypothesis that males and females donate the same amount of money $\left(\chi_{(17)}^{2}=122.63, p-\right.$ value $\left.=0.000\right)$. We reject the hypothesis that the probability of being solicited differs by $\operatorname{sex}\left(\chi_{(17)}^{2}=75.12, p-\right.$ value $\left.=0.000\right)$ and we reject the hypothesis that charitable solicitations have the same effect on males' and females' amount of charitable contributions $\left(\chi_{(1)}^{2}=47.12, p-\right.$ value $\left.=0.000\right)$.

Table 10 reports sensitivity tests for endogenous tobit models using the same additional explanatory variables that we employ in our previous models. For the full sample, we reject the null hypothesis that $\varphi=0$ at the $1 \%$ significance level for all specifications. Moreover, the coefficient, ATE, and ATT estimates in all specifications are significantly positive and remain substantially larger than the univariate tobit estimates. As in the bivariate probit model, the first specification reports the estimates of an endogenous tobit model without considering any identifying instruments. This model yields almost identical ATE and ATT coefficients as the estimates of the base model reported in the second specification.

In the third specification, we add three additional dummies to our base endogenous tobit model. Adding this variables decreases the ATE and ATT of being solicited on the amount of charitable contributions by $12 \%$ and $10 \%$. 
As in the bivariate model, adding the contributions by others does not considerably affect our original the ATE and ATT estimates. Adding this variable increases ATE and ATT estimates by only $1.5 \%$ and $3.4 \%$.

In the fifth specification, we control for the state effects. Including state dummies in our base endogenous tobit model increases the ATE of being solicited by $13 \%$ and the ATT by around $8 \%$. Finally, in specification six, we add charitable donations by others and three additional dummies to the model estimated in the fifth specification. In this model, the coefficient estimate, ATE and ATT of being solicited remains virtually the same as in the base model estimated in the second specification. In particular, the ATE increases by only 3\%, and the ATT increases by only $1.5 \%$.

In the rest of the specifications of Table 10, using the same explanatory variables, we report the results of the same sensitivity tests for males and females. For males, we reject the null hypothesis that $\varphi=0$ at $1 \%$ significance levels for all specifications except for the model in which we rely on the functional form assumptions for identification. Except for the models that control for the state fixed effects, the coefficient, ATE, and ATT estimates of the asked to give dummy are insignificant and negative. After controlling for the state effects, the ATE and ATT of charitable solicitations on the amount of donations are almost twice as large as in the single equation tobit estimates.

For females, the null hypothesis that $\varphi=0$ is rejected for all specifications. The coefficient, ATE, and ATT estimates remain significantly positive and larger than the univariate tobit estimates. Adding additional explanatory variables to our base model only slightly reduces our estimates except for the last specification, which predicts approximately a 5\% increase in the ATE and ATT relative to the base model.

\subsection{The validity of the instruments}

The PCP must satisfy two conditions to be a valid instrument for being solicited. First, it must be a determinant of being solicited. Second, it must not be a determinant of the propensity to give or the amount of charitable contributions, i.e., it must not be correlated with the error terms $u_{1}$ or $\varepsilon_{1}$. It is easy to show that PCP satisfies the first condition. As we have noted before, for the full sample, the coefficient of PCP is positive and significant at conventional significance levels in all bivariate probit models. Furthermore, a probit regression of the asked to give dummy on PCP yields a positive coefficient with a $z$-statistic of 4.19 .

Thus, the credibility of our estimations depends on whether the second condition is fulfilled. 
This condition is violated if people who live in a county where the number of public charities per capita is high are more likely to give or donate more than otherwise identical people who live in a county where fewer public charities are located ${ }^{29}$. There is no empirical evidence to suggest that the number of charities in a county is a significant determinant of the giving behavior of the county residents. Using our data, we can also provide some evidence that there is no considerable relationship between PCP and giving behavior. We divide our sample into two groups by PCP. People whose PCP value is less than or equal to the mean PCP represent those who live in a county where fewer number of public charities are located. Similarly, people who have higher PCP value than the mean value of PCP represent those who live in a county where more public charities are located. We find that these two groups are almost equally likely to donate $(91.44 \%$ and $91.47 \%)$ and donate virtually the same amount on average $(\$ 1,468$ and $\$ 1,451)$. Moreover, when we consider different quartiles of PCP, no significant difference exists in the giving behavior. For example, people in the 25th percentile are almost equally likely to donate when compared with people who are in the 50th, 75 th or 100th percentile (90\% compared with $93 \%, 92 \%$, and $91 \%$, respectively) and also donate almost the same amount $(\$ 1,465$ compared with $\$ 1,484, \$ 1,390$, and $\$ 1,498$, respectively).

A more formal way of testing the relationship between PCP and giving behavior is to include this variable in the single equation probit and tobit models, yet we recognize that this is not a proper test since if the correct econometric specifications are bivariate probit and endogenous tobit models then single equation models are misspecified and produce biased estimates. If we include PCP to the base single equation probit model, its estimated coefficient is positive but statistically insignificant with a $p$-value of 0.410 . If we include PCP to the base tobit model, its estimated coefficient is negative and statistically insignificant with a $p$-value of 0.487 . Therefore, our results indicate that there is no significant relationship between PCP and giving behavior.

While we recognize that it is not possible to test directly the validity of PCP as an instrument, we further conduct two test to explore this issue. First, we reestimate our models using alternative sets of instrumental variables to see whether our estimates are dependent on the selection of the instrument. Second, following Evans and Schwab (1995) and Lassen (2005), we test the validity of our instruments in the 2 SLS model ${ }^{30}$ using the tests of overidentification.

\footnotetext{
${ }^{29}$ Intuitively, this condition may also be violated if the number of public charities in a county affects the decision to live in that county. We believe this is highly implausible.

${ }^{30}$ Although Angrist (1991) suggests that the ATE in a bivariate probit model can be approximated via
} 
Although the dispersion of charitable organizations by population is homogenous in the sample, i.e., more charitable organizations are located in densely populated areas ${ }^{31}$, it is plausible that a few large charitable organizations with higher fundraising expenditures may be located in the same county. In this case, although the number of charities in this county is less than the average, the probability of being solicited would be higher due to the fundraising efforts of these charities. We explore this possibility using the IRS data set, which also reports information on the fundraising expenditures of public charities. Using this information, we calculate total fundraising expenditures for each county divided by population. We use the natural logarithm of this amount as an instrument. We expect that fundraising expenditures are positively associated with the probability of being solicited ${ }^{32}$, but that the propensity to give and amount of charitable contributions depend on fundraising expenditures only through charitable solicitations.

Finally, following the arguments of Bryant et. al. (2003) and Schervish and Havens (1997) that social interactions are the key determinant of charitable solicitations, we consider another instrument whether members of the respondent's household belong to any organizations other than a religious organization (belong to an organization). We expect that as members of a household become socially active, the probability of being solicited increases ${ }^{33}$. The data for this instrument come from the following question:

(Asked to all respondents) "Do members of your household belong to any other (other than a church, synagogue, mosque, or other formal religious organizations) organization? [If asked: For example, a service club such as Kiwanis or Rotary, an alumni organization, neighborhood organization, professional society, labor union or sports or hobby group.]"

Table 11 summarizes the ML estimates of models that rely on these alternative instruments. We use the same set of covariates that we employed in the base single equation probit and tobit models. In models (1) to (7), we report the coefficient of the asked to give dummy in the bivariate probit models. Our estimates with alternative instruments are quite similar to the base model 2SLS, there is no evidence to suggest that the assumptions necessary to perform the test of overidentifying restrictions are satisfied when both the dependent variable and the endogenous variable is binary. However, Evans and Schwab (1995) suggest that the test of overidentifying restrictions is the best diagnostic available.

${ }^{31}$ The correlation coefficient between the number of public charities and population is 0.951 . Regressing the number of public charities on population yields a t-statistic of 198.58 with $\mathrm{R}^{2}=0.905$.

${ }^{32}$ This hypothesis again can easily be verified. A probit regression of the asked to give dummy on this instrument yields a coefficient of 0.059 with a $z$-statistic of 4.90 .

${ }^{33} \mathrm{~A}$ probit regression of the asked to give dummy on this instrument yields a coefficient of 0.644 with a $z$-statistic of 12.39. Hence, 'belong to an organization' is a significant determinant of being solicited. 
estimate reported in model (1). In all models, we reject exogeneity of being solicited at the $1 \%$ level. The first stage F-test of excluded instruments (Bound et al., 1995) in all models suggest that our instruments are correlated with being solicited ${ }^{34}$. We cannot construct a test of overidentifying restrictions in exactly identified models, i.e., models (1), (2), and (4). In models (3) and (5), the null hypothesis that the instruments are valid clearly cannot be rejected. However, in the remaining models, this hypothesis can be rejected marginally, i.e., at the $10 \%$ level.

In models (8) to (14), we use the same instruments in the endogenous tobit models. As in the bivariate probit models, the coefficient estimates of models with alternative instruments are similar to the base model estimates reported in model (8). The first stage F-test statistics are well above their $1 \%$ critical value. The overidentification test suggests that our instruments are valid and do not belong directly in the estimating equation in models (10) and (12). However, we reject the hypothesis that our instruments are valid at the $5 \%$ level in models (13) and (14).

Since overidentification tests in linear 2SLS models confirm PCP and fundraising expenditures adjusted for population by county (FEP) as valid instruments, we suspect that the problem with models (13) and (14) comes from the belong to an organization dummy. We have already discussed that this variable is a significant determinant of being solicited. Thus, the credibility of this variable as an instrument depends on our assumption that after controlling for the observed factors, people who belong to an organization are not likely to donate more than otherwise identical people who are not a member of an organization. In order to investigate the relationship between belong to an organization and the amount of charitable contributions, we include this variable in both the propensity to be solicited and the amount of charitable contributions equations in the base endogenous tobit model and estimate this model using PCP and FEP as instruments. In this model, the estimated coefficient on belong to an organization was positive and statistically significant at the $1 \%$ level in the being solicited equation. However, it was positive but insignificant with a $p$-value of 0.189 in the amount of charitable giving equation. Therefore, we conclude that belong to an organization is a significant determinant of the probability of being solicited but not of the amount of charitable donations, and hence it can also serve as an appropriate instrument.

Smith and Blundell (1986) and Rivers and Vuong (1988) provide alternative exogeneity tests for probit and tobit models. The shortcoming of these tests however is that they only produce

\footnotetext{
${ }^{34}$ Another rule of thumb in the literature on weak instruments suggests that first stage F-test of excluded instruments in 2SLS regression should be larger than 10 (Staigler and Stock, 1997). All our models, except models (3) and (10) naturally pass this test.
} 
unbiased results when the endogenous variable is continuous. Nevertheless, we conduct these tests for both the probit and tobit models including our instruments. In the base probit model, we reject the exogeneity of being solicited both with the Smith and Blundell test of exogeneity $\left(\chi_{(1)}^{2}=7.65\right.$, $p-$ value $=0.006)$ and the Rivers-Voung test $\left(\chi_{(1)}^{2}=8.56, p-\right.$ value $\left.=0.003\right)$. Similarly, we reject the same hypothesis in the base tobit model both with the Smith and Blundell test $(F(1,2881)=$ 9.97, $p-$ value $=0.002)$ and the Rivers-Voung test $\left(\chi_{(1)}^{2}=36.83, p-\right.$ value $\left.=0.000\right)$.

Finally, in addition to the results of the overidentification tests and F-tests of excluded instruments in 2SLS models, some comfort on the appropriateness of our instruments can be derived from the statement of Angrist, Imbens and Rubin (1996). They argue that the stronger the instrument, the less sensitive the IV estimand to the violations of exclusionary restrictions. As we have shown in Table 8 and Table 10, the estimated coefficients are robust to functional form specifications, and they are also much the same regardless of the set of instruments employed. This is also the case in the linear 2SLS models estimated for the full sample.

\section{Conclusion and policy implications}

Although the theoretical and empirical research that has been devoted to understand the response of charitable donors to donation requests to give is very limited, asking has always been attributed as one the major fundraising techniques. Do donation requests indeed increase charitable giving? This is one of the fundamental policy questions that fundraisers would like to know the answer to. In this paper, we address this question using a unique survey that includes a question on whether the respondent is asked to give. The non-random selection of charitable donors makes the causal effect of charitable solicitations on the propensity to give and the amount of donations hard to estimate. In order to address the endogeneity of the probability of being solicited, we link our data set to the IRS data set on charitable organizations and the 2000 Census and propose appropriate instrumental variables.

We find that being solicited endogenously affects both the probability of giving and the amount of charitable contributions. Our results suggest that charitable solicitations have a substantial impact on giving behavior. This impact is even greater once the endogeneity is controlled for. We find that being solicited by a charity increases the propensity to give around $20 \%$ and almost triples the donation amount. Moreover, this effect is stable over different sets of instruments and in models with different configurations of explanatory variables. 
Although we recognize that our data set does not obtain sufficiently detailed information to assess the gender differences in giving behavior, we also estimate our models for males and females. We document that the giving patterns of males and females are significantly different. Both males and females are more likely to give when they are solicited. Although females seem to be more responsive to donation requests, this difference is not significant in both univariate and bivariate probit models.

We show that the probability of being solicited does not significantly differ by sex. Income, education, and age are significant determinants in being solicited to give. Strikingly, race also plays a key role in explaining the probability of being solicited. Whites are more likely to be asked to give and Hispanics are less likely to be solicited.

Our results reveal charitable solicitations as one of the most important reasons for why people contribute to charities. Yet, some important questions remain untouched, primarily due to the limitations of the survey data. First, although we know that most of the professional fundraising efforts rely on the face-to-face solicitations, we cannot measure the effect of the different modes of charitable solicitations on giving patterns, i.e., face-to-face solicitations versus direct-mailing or phone solicitations. Second, our empirical models do not include control variables for the characteristics of fundraisers and for the nature of fundraising campaigns. Recent experimental studies ${ }^{35}$ show that physical attractiveness of solicitors and various incentives such as announcing names of donors or offering gifts in exchange for charitable contributions can boost the effect of asking. Finally, the question of why are people more likely to give and even tend to give more only when they are asked to remains unanswered. As Freeman $(1993,1997)$ and Bryant et. al. (2003) suggest, one possible reason might be a social pressure effect. However, this hypothesis is not testable with the existing survey data. Hence, our study should be viewed as an important step in understanding the effect of charitable solicitations on giving patterns. Yet, future research can focus on how the impact of charitable solicitations would change under different incentives or due to the alternative settings of fundraising campaigns. Obviously, these call for more detailed survey and experimental data on charitable giving.

\footnotetext{
${ }^{35}$ See, for example, Landry et al. (2006).
} 


\section{References}

[1] Andreoni, J., 1989, Giving with impure altruism: Applications to charity and Ricardian Equivalence, Journal of Political Economy, 97, 1447-1458.

[2] Andreoni, J., 1990, Impure altruism and donations to public goods: A theory of warm glow giving, Economic Journal, 100, 464-477.

[3] Andreoni, J., 1998, Toward a theory of charitable fundraising, Journal of Political Economy, 106, 1186-1213.

[4] Andreoni, J. and A.A. Payne, 2003, Do government grants to private charities crowd out giving or fund-raising?, American Economic Review, 93, 792-812.

[5] Andreoni, J., E. Brown, and I. Rischall, 2003, Charitable Giving by Married Couples: Who Decides and Why Does it Matter?, Journal of Human Resources, 38, 111-133.

[6] Andreoni, J., 2006, Philanthropy, Handbook of Giving, Reciprocity and Altruism, S-C. Kolm and J. Mercier Ythier, eds., Amsterdam, North Holland, 1201-1269.

[7] Angrist, J.D., 1991, Instrumental variables estimation of average treatment effects in econometrics and epidemiology, National Bureau of Economic Research, Working Paper No. 115.

[8] Angrist, J.D., G.W. Imbens, and D.B. Rubin, 1996, Identification of causal effects using instrumental variables, Journal of American Statistical Association, 91, 444-455.

[9] Angrist, J.D., 2001, Estimation of limited dependent variable models with dummy endogenous regressors: Simple strategies for empirical practice, Journal of Business and Economic Statistics, 19, 2-16.

[10] Bound, J., D.A. Jaeger, and R. Baker, 1995, Problems with instrumental variables estimation when the correlation between the instruments and endogenous explanatory variable is weak, Journal of the American Statistical Association, 90, 443-450.

[11] Bryant, W.K., H. Jeon-Slaughter, H. Kang, and A. Tax, 2003, Participation in philianthropic activities: Donating money and time, Journal of Consumer Policy, 26, 43-73.

[12] Clotfelter, C.T., 1985, Federal tax policy and charitable giving, Chicago, University of Chicago Press. 
[13] Clotfelter, C.T., 1990, The impact of tax reform on charitable giving: A 1989 perspective, in Slemrod, J. eds., Do taxes matter? The impact of the tax reform act of 1986, Cambridge, MIT Press.

[14] Duncan, B., 1999, Modeling charitable contributions of time and money, Journal of Public Economics, 72, 213-242.

[15] Duncan, B., 2002, Pumpkin pies and public goods: The raffle fundraising strategy, Public Choice, 111, 49-71.

[16] Economides, N. and S. Rose-Ackerman, 1993, Differentiated Public Goods: Privatization and Optimality, in Does Economic Space Matter? Essays in Honour of Melvin L. Greenhut, edited by H. Ohta \& J.-F. Thisse. St. Martin's Press, NY.

[17] Evans, W.N. and R.M. Schwab,1995, Finishing high school and starting college: Do catholic schools make a difference?, Quarterly Journal of Economics, 110, 941-974.

[18] Freeman, R.B., 1993, Me, give to charity-Well, if you ask, Paper presented at the Conference on Happiness, Fairness, and Markets, London School of Economics, November 4-5.

[19] Freeman, R.B., 1997, Working for nothing: The supply of volunteer labor, Journal of Labor Economics, 15, 140-166.

[20] Glazer, A. and A.K. Kondrad, 1996, A signalling explanation for charity, American Economic Review, 86, 1019-1028.

[21] Greene, W., 1999, Marginal effects in the censored regression model, Economics Letters, 64, 43-49.

[22] Greene, W., 2003, Econometric Analysis, Fifth Edition, Pearson Education.

[23] Harbaugh, W.T., 1998, What do donations buy? A model of philanthrophy based on prestige and warm glow, Journal of Public Economics, 67, 269-284.

[24] Keegan, B., 1994, Fundraising for nonprofits: How to build a community partnership, Harper Collins Publishers, NY.

[25] Landry, C.E. et al., 2006, Toward an understanding of the economics of charity: Evidence from a field experiment, Quarterly Journal of Economics, 121, 747-782. 
[26] Lankford R.H. and J. H. Wyckkoff, 1991, Modelling charitable giving using a Box-Cox standard Tobit model, Review of Economics and Statistics, 73, 460-470.

[27] Lassen, D.D., 2005, The effect of information on voter turnout: Evidence from a natural experiment, American Journal of Political Science, 49, 103-118.

[28] Li, D. and A. Rettenmaier, 1999, The impact of insurance on medical expenditure: Tobit model with endogenous dummy variable, unpublished manuscript, Texas A\&M University, College Station, TX.

[29] List, J.A. and D. Lucking-Reiley, 2002, The effects of seed money and refunds on charitable giving: Experimental evidence from a university capital campaign, Journal of Political Economy, 110, 215-233.

[30] Maddala, G.S., 1983, Limited dependent and qualitative variables in econometrics, Cambridge University Press, Cambridge, UK.

[31] Mixer, J.R., 1993, Principles of successful fundraising: Useful foundations for successful practice, San Francisco, Jossey-Bass.

[32] Monfardini, C. and R. Radice, 2006, Testing exogeneity in the bivariate Probit model: A Monte Carlo study, unpublished manuscript, University of Bologna.

[33] Rivers, D. and Q. Vuong, 1988, Limited information estimators and exogeneity tests for simultaneous probit models, Journal of Econometrics, 39, 347-366.

[34] Rockefeller Brothers Fund, 1986, Report on charitable giving, New York, Rockefeller Brothers Fund.

[35] Romano, R. and H. Yildirim, 2001, Why charities announce donations: A positive perspective, Journal of Public Economics, 81, 423-447.

[36] Rose-Ackerman, S., 1982, Charitable giving and 'excessive' fundraising, Quarterly Journal of Economics, 97, 193-212.

[37] Schervish, P.G. and J.J. Havens, 1997, Social participation and charitable giving: A multivariate analysis, Voluntas: International Journal of Voluntary and Nonprofit Organizations, $8,235-260$. 
[38] Seymour, H., 1992, Designs for fund-raising: Principles, patterns, techniques, second edition, Taft Group.

[39] Smith, R. and R.W. Blundell, 1986, An exogeneity test for a simultaneous equation Tobit model with and application to labor supply, Econometrica, 54, 679-686.

[40] Staiger, D. and J.H. Stock, 1997, Instrumental variables regression with weak instruments, Econometrica, 65, 557-586.

[41] Vesterlund, L., 2006, Why do people give?, in R. Steinberg and W.W. Powell eds., The Nonprofit Sector, 2nd edition, Yale Press.

[42] Warner, I.R., 1975, The art of fundraising, New York, Harper-Row.

[43] Wooldridge, J.M., 2002, Econometric analysis of cross section and panel data, MIT Press, Cambridge, MA.

[44] Wilde, J., 2000, Identification of multiple equation Probit models with endogenous dummy regressors, Economics Letters, 69, 309-312.

\section{A Log-likelihood functions}

\section{A.1 Probit model with a binary endogenous variable}

The system of interest was

$$
\begin{gathered}
d_{i}^{*}=\beta_{1}^{\prime} X_{1 i}+\gamma \theta_{i}+u_{1 i} \\
\theta_{i}^{*}=\beta_{2}^{\prime} X_{2 i}+u_{2 i}
\end{gathered}
$$

where $\theta_{i}^{*}$ and $d_{i}^{*}$ are latent variables for the probability of being asked and the probability of giving respectively, and $\theta_{i}$ and $d_{i}$ are dichotomous variables observed according to the rule:

$$
\begin{aligned}
& d_{i}=1 \text { if } d_{i}^{*}>0 \text { and } 0 \text { otherwise, } \\
& \theta_{i}=1 \text { if } \theta_{i}^{*}>0 \text { and } 0 \text { otherwise. }
\end{aligned}
$$

The error terms are assumed to be independently and identically distributed as bivariate normal with $E\left[u_{1 i}\right]=E\left[u_{2 i}\right]=0, \operatorname{var}\left[u_{1 i}\right]=\operatorname{var}\left[u_{2 i}\right]=1$, and $\operatorname{cov}\left[u_{1 i}, u_{2 i}\right]=\rho$. For a single observation, the joint density of $\left(u_{1}, u_{2}\right)$ is:

$$
\phi\left(u_{1}, u_{2}\right)=\frac{1}{2 \pi(1-\rho)^{1 / 2}} \exp \left[-\frac{1}{2} \frac{u_{1}^{2}+u_{2}^{2}-2 \rho u_{1} u_{2}}{\left(1-\rho^{2}\right)}\right]
$$


and the likelihood functions for the joint events are defined as:

$$
\begin{gathered}
P\left(d_{1}=1, \theta_{1}=1\right)=\int_{-\left(\beta_{2}^{\prime} X_{2}\right)}^{\infty} \int_{-\left(\beta_{1}^{\prime} X_{1}+\gamma\right)}^{\infty} \phi\left(u_{1}, u_{2}\right) d u_{1} d u_{2} \\
P\left(d_{1}=1, \theta_{1}=0\right)=\int_{-\infty}^{-\left(\beta_{2}^{\prime} X_{2}\right)} \int_{-\left(\beta_{1}^{\prime} X_{1}\right)}^{\infty} \phi\left(u_{1}, u_{2}\right) d u_{1} d u_{2} \\
P\left(d_{1}=0, \theta_{1}=1\right)=\int_{-\left(\beta_{2}^{\prime} X_{2}\right)}^{\infty} \int_{-\infty}^{-\left(\beta_{1}^{\prime} X_{1}+\gamma\right)} \phi\left(u_{1}, u_{2}\right) d u_{1} d u_{2} \\
P\left(d_{1}=0, \theta_{1}=0\right)=\int_{-\infty}^{-\left(\beta_{2}^{\prime} X_{2}\right)} \int_{-\infty}^{-\left(\beta_{1}^{\prime} X_{1}\right)} \phi\left(u_{1}, u_{2}\right) d u_{1} d u_{2}
\end{gathered}
$$

Combining the four possible outcomes of $\left(d_{1}, \theta_{1}\right)$ and taking the logarithm gives the loglikelihood function. The likelihood corresponding to this set of events is a bivariate probit.

\section{A.2 Tobit model with a binary endogenous variable}

The system of interest was

$$
\begin{gathered}
\bar{d}_{i}^{*}=\alpha_{1}^{\prime} X_{1 i}+\eta \theta_{i}+\varepsilon_{1 i} \\
\theta_{i}^{*}=\alpha_{2}^{\prime} X_{2 i}+\varepsilon_{2 i}
\end{gathered}
$$

where $\bar{d}_{i}$ and $\theta_{i}$ are observed according to the following rule:

$$
\begin{gathered}
\bar{d}_{i}=\max \left\{\left(\alpha_{1}^{\prime} X_{1 i}+\eta \theta_{i}+\varepsilon_{1 i}\right), 0\right\}, \\
\theta_{i}=1 \text { if } \theta_{i}^{*}>0 \text { and } 0 \text { otherwise }
\end{gathered}
$$

where the error terms are assumed to be independently and identically distributed as bivariate normal with $E\left[\varepsilon_{1 i}\right]=E\left[\varepsilon_{2 i}\right]=0, \operatorname{var}\left[\varepsilon_{1 i}\right]=\sigma^{2}$ and $\operatorname{var}\left[\varepsilon_{2 i}\right]=1$, and $\operatorname{cov}\left[\varepsilon_{1 i}, \varepsilon_{2 i}\right]=\varphi \sigma$. Following $\mathrm{Li}$ and Rettenmaier (1999), we consider four possible outcomes separately. The likelihood function for the joint probability of $\bar{d}_{1}>0$ and $\theta_{1}=1$ is

$$
\begin{array}{r}
f\left(\bar{d}_{1}>0, \theta_{1}=1\right)=\int_{-\left(\alpha_{2}^{\prime} X_{2}\right)}^{\infty} f\left(\varepsilon_{1}, \varepsilon_{2}\right) d \varepsilon_{2} \\
=\int_{-\left(\alpha_{2}^{\prime} X_{2}\right)}^{\infty} f\left(\varepsilon_{2} \mid \varepsilon_{1}\right) f\left(\varepsilon_{1}\right) d \varepsilon_{2} \\
=f\left(\varepsilon_{1}\right) \int_{-\left(\alpha_{2}^{\prime} X_{2}\right)}^{\infty} f\left(\varepsilon_{2} \mid \varepsilon_{1}\right) d \varepsilon_{2} \\
=f\left(\varepsilon_{1}\right)\left[1-\Phi\left(\frac{-\left(\alpha_{2}^{\prime} X_{2}\right)-\varphi \sigma \varepsilon_{1}}{\left(1-\varphi^{2}\right)^{1 / 2}}\right)\right] \\
=f\left(\varepsilon_{1}\right) \Phi\left(\frac{\left(\alpha_{1}^{\prime} X_{2}\right)+\varphi \sigma \varepsilon_{1}}{\left(1-\varphi^{2}\right)^{1 / 2}}\right)
\end{array}
$$

where $\varepsilon_{1}=\bar{d}-\alpha_{1}^{\prime} X_{1}-\eta$ and $f\left(\varepsilon_{1}\right)=\frac{1}{\left(2 \pi \sigma^{2}\right)^{1 / 2}} \exp \left[-\frac{1}{2} \frac{\varepsilon_{1}^{2}}{\sigma^{2}}\right]$.

The likelihood function for the joint probability of $\bar{d}_{1}>0$ and $\theta_{1}=0$ is

$$
\begin{gathered}
f\left(\bar{d}_{1}>0, \theta_{1}=0\right)=\int_{-\infty}^{-\left(\alpha_{2}^{\prime} X_{2}\right)} f\left(\varepsilon_{1}, \varepsilon_{2}\right) d \varepsilon_{2} \\
=f\left(\varepsilon_{1}\right) \Phi\left(\frac{-\left(\alpha_{2}^{\prime} X_{2}\right)-\varphi \sigma \varepsilon_{1}}{\left(1-\varphi^{2}\right)^{1 / 2}}\right) \\
=f\left(\varepsilon_{1}\right)\left[1-\Phi\left(\frac{\left(\alpha_{2}^{\prime} X_{2}\right)+\varphi \sigma \varepsilon_{1}}{\left(1-\varphi^{2}\right)^{1 / 2}}\right)\right]
\end{gathered}
$$


where $\varepsilon_{1}=\bar{d}-\alpha_{1}^{\prime} X_{1}$ and $f\left(\varepsilon_{1}\right)=\frac{1}{\left(2 \pi \sigma^{2}\right)^{1 / 2}} \exp \left[-\frac{1}{2} \frac{\varepsilon_{1}^{2}}{\sigma^{2}}\right]$.

The likelihood function for the joint probability of $\left(\bar{d}_{1}=0\right.$ and $\left.\theta_{1}=0\right)$ and $\overline{(d}_{1}=0$ and $\left.\theta_{1}=1\right)$ are the same as the likelihood functions of those corresponding events in the probit model with the endogenous binary regressor (bivariate probit model), where $\left(\varepsilon_{1}, \varepsilon_{2}\right)$ is distributed as a bivariate normal. Combining the four possible outcomes of $\left(\bar{d}_{1}, \theta_{1}\right)$ and taking the logarithm gives the log-likelihood function for this model. Finally, estimation of this model with multiple binary endogenous variables is also possible using the methodology discussed in Li and Rettenmaier (1999). 


\section{B Definition of key variables}

Variable Name Defination

\section{Dependent Variables}

give

total charitable contributions

\section{Independent Variables}

asked to give

income

price

age

family size

married

employed

white, black, hispanic

male

education dummies

attends religious services

homeowner

vote

born in USA

charitable contributions by others

\section{Instrumental Variables}

No. of charitable org./population (PCP)

Fundraising expenditures/population (FEP)

Belong to an organization (belong)
Binary giving variable. 1 if the respondent donated any amount to a charitable organization in 2000.

Total amount of money that the respondent has reported giving to charity in 2000, expressed in 2000 dollars.

Equals 1 if the respondent has reported being personally solicited by some charity during the survey year.

Total household income.

Equals 1 minus marginal tax rate for itemizers, 1 for nonitemizers. Calculated using Federal and State tax schedules for 2000, information on income, marrital status, and itemization status.

Age of the respondent.

Total number of people living in the household including the respondent.

Equals 1 if the respondent is married.

Equals 1 if the respondent is employed.

Binary variables for the race of the respondent.

Equals 1 if the respondent is male.

Binary variables for the highest level of education obtained. The omitted category is those who did not complete high school.

Equals 1 if the respondent has reported that he/she personally attends religious services for every week or nearly every week.

Equals 1 if the respondent owns his/her primary residence.

Equals 1 if the respondent voted in the past presenditial election.

Equals 1 if the respondent was born in USA.

Total amount of charitable contributions in a county, where the respondent resides. Excludes the contribution of the current household.

Number of charitable organizations divided by population, by county.

Natural logarithm of the total fundraising expenditures divided by population, by county.

Equals 1 if members of respondent's household belong to any organization other than a religious organization. 


\section{Tables}

Table 1. The Characteristics of Charitable Donors and Nondonors

\begin{tabular}{|c|c|c|c|c|c|c|}
\hline & \multicolumn{2}{|c|}{ Full sample } & \multicolumn{2}{|c|}{ Males } & \multicolumn{2}{|c|}{ Females } \\
\hline & Donor & Nondonor & Donor & Nondonor & Donor & Nondonor \\
\hline Percentage male & 37.60 & 36.79 & - & - & - & - \\
\hline Percentage white & 84.94 & 72.40 & 83.34 & 83.83 & 83.83 & 66.81 \\
\hline Percentage black & 9.67 & 15.93 & 9.96 & 9.98 & 12.26 & 21.75 \\
\hline Percentage Hispanic & 7.26 & 13.92 & 8.04 & 8.20 & 6.36 & 12.62 \\
\hline Percentage married & 48.89 & 30.26 & 27.50 & 17.01 & 28.24 & 14.25 \\
\hline Percentage employed & 64.54 & 50.18 & 71.17 & 64.99 & 60.18 & 42.39 \\
\hline Percentage college graduate & 31.78 & 13.84 & 34.99 & 20.60 & 29.42 & 10.19 \\
\hline Percentage regularly attend religious services & 43.59 & 18.51 & 29.91 & 5.79 & 46.18 & 20.82 \\
\hline Mean age & $\begin{array}{c}48.88 \\
(16.65)\end{array}$ & $\begin{array}{c}47.95 \\
(18.42)\end{array}$ & $\begin{array}{c}46.81 \\
(16.81)\end{array}$ & $\begin{array}{c}44.82 \\
(17.88)\end{array}$ & $\begin{array}{c}51.46 \\
(17.27)\end{array}$ & $\begin{array}{c}52.91 \\
(18.62)\end{array}$ \\
\hline Mean family size & $\begin{array}{c}2.48 \\
(1.40)\end{array}$ & $\begin{array}{c}2.26 \\
(1.44)\end{array}$ & $\begin{array}{c}2.02 \\
(1.31)\end{array}$ & $\begin{array}{c}1.78 \\
(1.27)\end{array}$ & $\begin{array}{c}2.14 \\
(1.32)\end{array}$ & $\begin{array}{c}1.89 \\
(1.26)\end{array}$ \\
\hline Mean household income & $\begin{array}{c}54,490 \\
(45,091)\end{array}$ & $\begin{array}{c}28,711 \\
(22,688)\end{array}$ & $\begin{array}{c}54,004 \\
(48,581)\end{array}$ & $\begin{array}{l}39,154 \\
(27,443)\end{array}$ & $\begin{array}{c}44,844 \\
(41,317)\end{array}$ & $\begin{array}{c}20,588 \\
(15,668)\end{array}$ \\
\hline Mean amount of money contributions & $\begin{array}{c}1,613 \\
(3,136)\end{array}$ & - & $\begin{array}{c}1,354 \\
(2,618)\end{array}$ & - & $\begin{array}{c}1,241 \\
(2,419)\end{array}$ & - \\
\hline $\begin{array}{l}\text { Mean amount of money contributions as a percentage } \\
\text { of household income }\end{array}$ & $\begin{array}{l}3.15 \\
(4.43)\end{array}$ & - & $\begin{array}{l}2.80 \\
(4.35)\end{array}$ & - & $\begin{array}{c}3.09 \\
(4.33)\end{array}$ & - \\
\hline
\end{tabular}

Notes: The maximum sample for the survey is 4,216. The number of observations for each variable varies modestly due to nonrespondents. Sample weighted means are reported. Standard deviations are in parenthesis. 
Table 2. The relationship between charitable solicitations and giving decision

\begin{tabular}{|c|c|c|c|c|c|c|c|c|c|c|c|c|}
\hline \multirow[b]{2}{*}{ Were you asked to give? } & \multicolumn{4}{|c|}{ Full Sample } & \multicolumn{4}{|c|}{ Males } & \multicolumn{4}{|c|}{ Females } \\
\hline & \multicolumn{2}{|c|}{ Yes } & \multicolumn{2}{|c|}{ No } & \multicolumn{2}{|c|}{ Yes } & \multicolumn{2}{|c|}{ No } & \multicolumn{2}{|c|}{ Yes } & \multicolumn{2}{|c|}{ No } \\
\hline & \multicolumn{2}{|c|}{$57.68 \%$} & \multicolumn{2}{|c|}{$42.32 \%$} & \multicolumn{2}{|c|}{$\begin{array}{l}54.92 \% \\
(\mathrm{n}=474)\end{array}$} & \multicolumn{2}{|c|}{$\begin{array}{l}45.08 \% \\
(\mathrm{n}=389)\end{array}$} & \multicolumn{2}{|c|}{$\begin{array}{l}58.11 \% \\
(\mathrm{n}=892)\end{array}$} & \multicolumn{2}{|c|}{$\begin{array}{l}41.89 \% \\
(\mathrm{n}=643)\end{array}$} \\
\hline \multirow[t]{2}{*}{ Donated money? } & Yes & No & Yes & No & Yes & No & Yes & No & Yes & No & Yes & No \\
\hline & $\begin{array}{c}97.38 \% \\
(\mathrm{n}=2,346)\end{array}$ & $\begin{array}{l}2.62 \% \\
(\mathrm{n}=63)\end{array}$ & $\begin{array}{c}84.61 \% \\
(\mathrm{n}=1,490)\end{array}$ & $\begin{array}{l}15.39 \% \\
(\mathrm{n}=271)\end{array}$ & $\begin{array}{l}94.73 \% \\
(\mathrm{n}=449)\end{array}$ & $\begin{array}{l}5.27 \% \\
(\mathrm{n}=25)\end{array}$ & $\begin{array}{l}84.42 \% \\
(\mathrm{n}=325)\end{array}$ & $\begin{array}{l}15.58 \% \\
(\mathrm{n}=60)\end{array}$ & $\begin{array}{l}96.97 \% \\
(\mathrm{n}=865)\end{array}$ & $\begin{array}{l}3.03 \% \\
(\mathrm{n}=27)\end{array}$ & $\begin{array}{l}84.74 \% \\
(\mathrm{n}=545)\end{array}$ & $\begin{array}{l}15.26 \% \\
(\mathrm{n}=98)\end{array}$ \\
\hline Mean amount donated & & & & & \multicolumn{2}{|c|}{$\begin{array}{c}1,675 \\
(2,916)\end{array}$} & \multicolumn{2}{|c|}{$\begin{array}{c}903 \\
(2,050)\end{array}$} & \multicolumn{2}{|c|}{$\begin{array}{c}1,475 \\
(2,791)\end{array}$} & \multicolumn{2}{|c|}{$\begin{array}{c}856 \\
(1,557)\end{array}$} \\
\hline $\begin{array}{l}\text { Mean amount donated as a percentage of } \\
\text { income }\end{array}$ & \multicolumn{2}{|c|}{3.45} & \multicolumn{2}{|c|}{2.67} & \multicolumn{2}{|c|}{3.12} & \multicolumn{2}{|c|}{2.34} & \multicolumn{2}{|c|}{3.32} & \multicolumn{2}{|c|}{2.72} \\
\hline
\end{tabular}

Notes: Sample weighted means are reported. Standard deviations are in parenthesis. 
Table 3. Determinants of the probability of giving

\begin{tabular}{|c|c|c|c|c|c|c|}
\hline \multirow[b]{3}{*}{ Explanatory Variables } & \multicolumn{2}{|c|}{ Full Sample } & \multicolumn{2}{|c|}{ Males } & \multicolumn{2}{|c|}{ Females } \\
\hline & (1) & $(2)$ & $(3)$ & (4) & $(5)$ & (6) \\
\hline & Coefficient & $\begin{array}{c}\text { Marginal } \\
\text { Effect }\end{array}$ & Coefficient & $\begin{array}{c}\text { Marginal } \\
\text { Effect }\end{array}$ & Coefficient & $\begin{array}{c}\text { Marginal } \\
\text { Effect }\end{array}$ \\
\hline \multirow[t]{2}{*}{ Asked to give } & 0.711 & 0.073 & 0.552 & 0.072 & 0.627 & 0.061 \\
\hline & $(0.073)^{* *}$ & $(0.008)^{* *}$ & $(0.142)^{* *}$ & $(0.018)^{* *}$ & $(0.117)^{* *}$ & $(0.013)^{* *}$ \\
\hline \multirow[t]{2}{*}{$\ln ($ price) } & -0.615 & -0.056 & -0.213 & -0.026 & -0.589 & -0.051 \\
\hline & $(0.239)^{* *}$ & $(0.022)^{* *}$ & $(0.442)$ & $(0.055)$ & $(0.446)$ & $(0.037)$ \\
\hline \multirow[t]{2}{*}{ ln (household income) } & 0.228 & 0.021 & -0.037 & -0.005 & 0.303 & 0.026 \\
\hline & $(0.049)^{* *}$ & $(0.005)^{* *}$ & $(0.105)$ & $(0.013)$ & $(0.082)^{* *}$ & $(0.008)^{* *}$ \\
\hline \multirow{2}{*}{ Age } & 0.002 & 0.000 & 0.027 & 0.003 & -0.014 & -0.001 \\
\hline & $(0.012)$ & $(0.001)$ & $(0.024)$ & $(0.003)$ & $(0.019)$ & $(0.002)$ \\
\hline \multirow{2}{*}{$\operatorname{Age}^{2}(\times 100)$} & 0.004 & 0.000 & -0.019 & -0.002 & 0.016 & 0.001 \\
\hline & $(0.012)$ & $(0.001)$ & $(0.024)$ & $(0.003)$ & $(0.018)$ & $(0.002)$ \\
\hline \multirow{2}{*}{ Family size } & 0.064 & 0.006 & 0.092 & 0.011 & 0.071 & 0.006 \\
\hline & $(0.030)^{*}$ & $(0.003)^{*}$ & $(0.068)$ & $(0.008)$ & $(0.052)$ & $(0.005)$ \\
\hline \multirow{2}{*}{ Employed } & 0.230 & 0.022 & 0.309 & 0.042 & 0.206 & 0.018 \\
\hline & $(0.081)^{* *}$ & $(0.008)^{* *}$ & $(0.180)$ & $(0.027)$ & $(0.137)$ & $(0.013)$ \\
\hline \multirow{2}{*}{ Married } & 0.017 & 0.002 & -0.092 & -0.012 & -0.044 & -0.004 \\
\hline & $(0.081)$ & $(0.007)$ & $(0.185)$ & $(0.025)$ & $(0.152)$ & $(0.014)$ \\
\hline \multirow[t]{2}{*}{ White } & 0.281 & 0.030 & -0.237 & -0.026 & 0.592 & 0.072 \\
\hline & $(0.125)^{*}$ & $(0.016)^{*}$ & $(0.298)$ & $(0.029)$ & $(0.211)^{* *}$ & $(0.033)^{* *}$ \\
\hline \multirow[t]{2}{*}{ Black } & 0.074 & 0.006 & -0.319 & -0.048 & 0.205 & 0.016 \\
\hline & $(0.149)$ & $(0.012)$ & $(0.370)$ & $(0.066)$ & $(0.233)$ & $(0.015)$ \\
\hline \multirow[t]{2}{*}{ Hispanic } & -0.054 & -0.005 & 0.061 & 0.007 & -0.144 & -0.014 \\
\hline & $(0.122)$ & $(0.012)$ & $(0.288)$ & $(0.033)$ & $(0.204)$ & $(0.022)$ \\
\hline Male & $\begin{array}{l}-0.058 \\
(0.068)\end{array}$ & $\begin{array}{l}-0.005 \\
(0.006)\end{array}$ & - & - & - & - \\
\hline \multirow{2}{*}{ High School (=1) } & 0.333 & 0.027 & 0.497 & 0.052 & 0.220 & 0.018 \\
\hline & $(0.094)^{* *}$ & $(0.007)^{* *}$ & $(0.197)^{*}$ & $(0.018)^{* *}$ & $(0.155)$ & $(0.012)$ \\
\hline \multirow[t]{2}{*}{ Some College $(=1)$} & 0.694 & 0.050 & 1.046 & 0.096 & 0.459 & 0.034 \\
\hline & $(0.112)^{* *}$ & $(0.007)^{* *}$ & $(0.219)^{* *}$ & $(0.017)^{* *}$ & $(0.181)^{*}$ & $(0.012)^{* *}$ \\
\hline \multirow[t]{2}{*}{ College $(=1)$} & 0.460 & 0.033 & 0.778 & 0.069 & 0.292 & 0.021 \\
\hline & $(0.125)^{* *}$ & $(0.007)^{* *}$ & $(0.239)^{* *}$ & $(0.016)^{* *}$ & $(0.216)$ & $(0.014)$ \\
\hline \multirow[t]{2}{*}{ Graduate School (=1) } & 0.736 & 0.042 & 1.115 & 0.077 & 1.076 & 0.048 \\
\hline & $(0.174)^{* *}$ & $(0.006)^{* *}$ & $(0.301)^{* *}$ & $(0.013) * *$ & $(0.464)^{*}$ & $(0.009)^{* *}$ \\
\hline \multirow[t]{2}{*}{ Attends religious services } & 0.608 & 0.052 & 1.018 & 0.093 & 0.645 & 0.054 \\
\hline & $(0.080)^{* *}$ & $(0.007)^{* *}$ & $(0.203)^{* *}$ & $(0.015)^{* *}$ & $(0.125)^{* *}$ & $(0.012)^{* *}$ \\
\hline \multirow[t]{2}{*}{ Intercept } & -2.636 & & -0.349 & & -2.971 & \\
\hline & $(0.561)^{* *}$ & & $(1.194)$ & & $(0.941)^{* *}$ & \\
\hline $\begin{array}{l}\text { Average treatment effect (Asked } \\
\text { to give) }\end{array}$ & $\begin{array}{c}0.082 \\
(0.008)^{* *}\end{array}$ & & $\begin{array}{c}0.070 \\
(0.018)^{* *}\end{array}$ & & $\begin{array}{c}0.064 \\
(0.012)^{* *}\end{array}$ & \\
\hline $\begin{array}{l}\text { Average treatment effect on the } \\
\text { treated (Asked to give) }\end{array}$ & $\begin{array}{c}0.068 \\
(0.007)^{* *}\end{array}$ & & $\begin{array}{c}0.061 \\
(0.016)^{* *}\end{array}$ & & $\begin{array}{c}0.052 \\
(0.010)^{* *}\end{array}$ & \\
\hline Pseudo $\mathrm{R}^{2}$ & 0.218 & & 0.165 & & 0.228 & \\
\hline Log-likelihood & -942.086 & & -233.188 & & -343.157 & \\
\hline Number of Observations & 4093 & & 845 & & 1503 & \\
\hline
\end{tabular}

Notes: Sample weights are used in all regressions. Robust standard errors are reported in parenthesis. The sign * indicates that the variable is significant at $5 \%$ significance level. The sign ** indicates that the variable is significant at $1 \%$ significance level. 
Table 4. Determinants of being solicited

\begin{tabular}{|c|c|c|c|c|c|c|}
\hline \multirow[b]{3}{*}{ Explanatory Variables } & \multicolumn{2}{|c|}{ Full Sample } & \multicolumn{2}{|c|}{ Males } & \multicolumn{2}{|c|}{ Females } \\
\hline & (1) & $(2)$ & $(3)$ & $(4)$ & $(5)$ & $(6)$ \\
\hline & Coefficient & $\begin{array}{c}\text { Marginal } \\
\text { Effect }\end{array}$ & Coefficient & $\begin{array}{l}\text { Marginal } \\
\text { Effect }\end{array}$ & Coefficient & $\begin{array}{c}\text { Marginal } \\
\text { Effect }\end{array}$ \\
\hline \multirow[t]{2}{*}{$\overline{\ln \text { (price) }}$} & -0.119 & -0.047 & -0.623 & -0.247 & 0.056 & 0.022 \\
\hline & $(0.130)$ & $(0.051)$ & $(0.286)^{*}$ & $(0.113)^{* *}$ & $(0.231)$ & $(0.090)$ \\
\hline \multirow[t]{2}{*}{ ln (household income) } & 0.227 & 0.089 & 0.261 & 0.104 & 0.201 & 0.079 \\
\hline & $(0.036)^{* *}$ & $(0.014)^{* *}$ & $(0.078)^{* *}$ & $(0.031)^{* *}$ & $(0.058)^{* *}$ & $(0.023)^{* *}$ \\
\hline \multirow[t]{2}{*}{ Age } & 0.036 & 0.014 & 0.027 & 0.011 & 0.044 & 0.017 \\
\hline & $(0.008)^{* *}$ & $(0.003)^{* *}$ & $(0.016)$ & $(0.006)$ & $(0.013)^{* *}$ & $(0.005)^{* *}$ \\
\hline \multirow[t]{2}{*}{$\operatorname{Age}^{2}(\times 100)$} & -0.031 & -0.012 & -0.025 & -0.010 & -0.035 & -0.014 \\
\hline & $(0.008)^{* *}$ & $(0.003)^{* *}$ & $(0.016)$ & $(0.006)$ & $(0.012)^{* *}$ & $(0.005)^{* *}$ \\
\hline \multirow[t]{2}{*}{ Family size } & -0.015 & -0.006 & -0.061 & -0.024 & -0.003 & -0.001 \\
\hline & $(0.018)$ & $(0.007)$ & $(0.043)$ & $(0.017)$ & $(0.032)$ & $(0.013)$ \\
\hline \multirow[t]{2}{*}{ Employed } & -0.015 & -0.006 & -0.277 & -0.108 & 0.181 & 0.071 \\
\hline & $(0.054)$ & $(0.021)$ & $(0.135)^{*}$ & $(0.052)$ & $(0.087)^{*}$ & $(0.034)^{*}$ \\
\hline \multirow[t]{2}{*}{ Married } & 0.080 & 0.031 & 0.192 & 0.076 & 0.165 & 0.064 \\
\hline & $(0.051)$ & $(0.020)$ & $(0.124)$ & $(0.048)$ & $(0.090)$ & $(0.034)$ \\
\hline \multirow[t]{2}{*}{ White } & 0.272 & 0.108 & 0.349 & 0.138 & 0.331 & 0.131 \\
\hline & $(0.092)^{* *}$ & $(0.037)^{* *}$ & $(0.183)^{*}$ & $(0.072)^{*}$ & $(0.166)^{*}$ & $(0.066)^{*}$ \\
\hline \multirow[t]{2}{*}{ Black } & 0.165 & 0.064 & 0.041 & 0.016 & 0.250 & 0.095 \\
\hline & $(0.111)$ & $(0.042)$ & $(0.227)$ & $(0.090)$ & $(0.188)$ & $(0.070)$ \\
\hline \multirow[t]{2}{*}{ Hispanic } & -0.248 & -0.099 & -0.167 & -0.067 & -0.060 & -0.023 \\
\hline & $(0.087)^{* *}$ & $(0.035)^{* *}$ & $(0.181)$ & $(0.072)$ & $(0.145)$ & $(0.057)$ \\
\hline \multirow[t]{2}{*}{ Male } & -0.047 & -0.018 & - & - & - & - \\
\hline & $(0.043)$ & $(0.017)$ & & & & \\
\hline \multirow[t]{2}{*}{ High School (=1) } & 0.199 & 0.077 & 0.078 & 0.031 & 0.200 & 0.077 \\
\hline & $(0.074)^{* *}$ & $(0.029)^{* *}$ & $(0.165)$ & $(0.065)$ & $(0.121)$ & $(0.047)$ \\
\hline \multirow[t]{2}{*}{ Some College $(=1)$} & 0.383 & 0.147 & 0.090 & 0.036 & 0.355 & 0.136 \\
\hline & $(0.078)^{* *}$ & $(0.029)^{* *}$ & $(0.170)$ & $(0.067)$ & $(0.130)^{* *}$ & $(0.048)^{* *}$ \\
\hline \multirow[t]{2}{*}{ College $(=1)$} & 0.524 & 0.195 & 0.212 & 0.083 & 0.495 & 0.183 \\
\hline & $(0.087)^{* *}$ & $(0.030)^{* *}$ & $(0.184)$ & $(0.071)$ & $(0.148)^{* *}$ & $(0.051)^{* *}$ \\
\hline \multirow[t]{2}{*}{ Graduate School $(=1)$} & 0.759 & 0.266 & 0.436 & 0.166 & 0.808 & 0.277 \\
\hline & $(0.098)^{* *}$ & $(0.029)^{* *}$ & $(0.207)^{*}$ & $(0.075)^{*}$ & $(0.172)^{* *}$ & $(0.048)^{* *}$ \\
\hline \multirow[t]{2}{*}{ Attends religious services } & 0.104 & 0.041 & 0.064 & 0.025 & 0.089 & 0.035 \\
\hline & $(0.045)^{*}$ & $(0.018)^{*}$ & $(0.109)$ & $(0.043)$ & $(0.073)$ & $(0.029)$ \\
\hline \multirow[t]{2}{*}{ Intercept } & -3.795 & & -3.571 & & -3.901 & \\
\hline & $(0.399)^{* *}$ & & $(0.859)^{* *}$ & & $(0.652)^{* *}$ & \\
\hline Pseudo $\mathrm{R}^{2}$ & 0.077 & & 0.078 & & 0.076 & \\
\hline Log-likelihood & -2586.880 & & -538.327 & & -947.907 & \\
\hline Number of Observations & 4096 & & 847 & & 1503 & \\
\hline
\end{tabular}

Notes: Sample weights are used in all regressions. Robust standard errors are reported in parenthesis. The sign $*$ indicates that the variable is significant at $5 \%$ significance level. The sign $* *$ indicates that the variable is significant at $1 \%$ significance level. 
Table 5. Determinants of the amount of charitable contributions

\begin{tabular}{|c|c|c|c|c|c|c|}
\hline \multirow[b]{3}{*}{ Explanatory Variables } & \multicolumn{2}{|c|}{ Full Sample } & \multicolumn{2}{|c|}{ Males } & \multicolumn{2}{|c|}{ Females } \\
\hline & (1) & $(2)$ & (3) & (4) & $(5)$ & $(6)$ \\
\hline & Coefficient & $\begin{array}{l}\text { Marginal } \\
\text { Effect }\end{array}$ & Coefficient & $\begin{array}{l}\text { Marginal } \\
\text { Effect }\end{array}$ & Coefficient & $\begin{array}{l}\text { Marginal } \\
\text { Effect }\end{array}$ \\
\hline \multirow[t]{2}{*}{ Asked to give } & 1.055 & 0.989 & 1.077 & 0.940 & 0.995 & 0.931 \\
\hline & $(0.087)^{* *}$ & $(0.079)^{* *}$ & $(0.212)^{* *}$ & $(0.183)^{* *}$ & $(0.140)^{* *}$ & $(0.128)^{* *}$ \\
\hline \multirow[t]{2}{*}{$\ln$ (price) } & -1.293 & -1.221 & -0.940 & -0.825 & -1.328 & -1.250 \\
\hline & $(0.242)^{* *}$ & $(0.228)^{* *}$ & $(0.623)$ & $(0.547)$ & $(0.397)^{* *}$ & $(0.374)^{* *}$ \\
\hline \multirow[t]{2}{*}{ ln (household income) } & 0.796 & 0.752 & 0.462 & 0.406 & 0.832 & 0.783 \\
\hline & $(0.074)^{* *}$ & $(0.069)^{* *}$ & $(0.170)^{* *}$ & $(0.150)^{* *}$ & $(0.120)^{* *}$ & $(0.112)$ \\
\hline \multirow[t]{2}{*}{ Age } & 0.026 & 0.025 & 0.089 & 0.078 & 0.025 & $(0.024)$ \\
\hline & $(0.016)$ & $(0.015)$ & $(0.038)^{*}$ & $(0.034)^{*}$ & $(0.025)$ & $(0.024)$ \\
\hline \multirow[t]{2}{*}{$\operatorname{Age}^{2}(\times 100)$} & -0.008 & -0.008 & -0.059 & -0.052 & -0.008 & -0.007 \\
\hline & $(0.016)$ & $(0.015)$ & $(0.038)$ & $(0.033)$ & $(0.023)$ & $(0.022)$ \\
\hline \multirow[t]{2}{*}{ Family size } & 0.108 & 0.102 & 0.262 & 0.230 & 0.113 & 0.106 \\
\hline & $(0.037)^{* *}$ & $(0.035)^{* *}$ & $(0.102)^{*}$ & $(0.090)^{*}$ & $(0.062)$ & $(0.058)$ \\
\hline \multirow[t]{2}{*}{ Employed } & 0.196 & 0.184 & 0.287 & 0.251 & 0.152 & 0.143 \\
\hline & $(0.105)$ & $(0.099)$ & $(0.299)$ & $(0.260)$ & $(0.165)$ & $(0.155)$ \\
\hline \multirow[t]{2}{*}{ Married } & 0.140 & 0.132 & -0.003 & -0.003 & -0.068 & -0.064 \\
\hline & $(0.098)$ & $(0.092)$ & $(0.245)$ & $(0.215)$ & $(0.161)$ & $(0.151)$ \\
\hline \multirow{2}{*}{ White } & 0.644 & 0.599 & 0.380 & 0.330 & 0.903 & 0.834 \\
\hline & $(0.198)^{* *}$ & $(0.182)^{* *}$ & $(0.381)$ & $(0.328)$ & $(0.378)^{*}$ & $(0.342)^{*}$ \\
\hline \multirow[t]{2}{*}{ Black } & 0.282 & 0.268 & 0.122 & 0.107 & 0.433 & 0.411 \\
\hline & $(0.237)$ & $(0.226)$ & $(0.491)$ & $(0.435)$ & $(0.416)$ & $(0.398)$ \\
\hline \multirow[t]{2}{*}{ Hispanic } & -0.246 & -0.231 & -0.326 & -0.282 & -0.254 & -0.237 \\
\hline & $(0.189)$ & $(0.176)$ & $(0.405)$ & $(0.347)$ & $(0.326)$ & $(0.303)$ \\
\hline \multirow[t]{2}{*}{ Male } & 0.089 & 0.084 & - & - & - & - \\
\hline & $(0.081)$ & $(0.077)$ & & & & \\
\hline \multirow[t]{2}{*}{ High School (=1) } & 1.002 & 0.954 & 1.126 & 1.007 & 1.481 & 1.408 \\
\hline & $(0.189)^{* *}$ & $(0.181)^{* *}$ & $(0.460)^{*}$ & $(0.417)^{*}$ & $(0.307)^{* *}$ & $(0.293)$ \\
\hline \multirow[t]{2}{*}{ Some College $(=1)$} & 1.572 & 1.504 & 2.088 & 1.891 & 1.928 & 1.845 \\
\hline & $(0.189)^{* *}$ & $(0.182)^{* *}$ & $(0.453)^{* *}$ & $(0.415)^{* *}$ & $(0.311)^{* *}$ & $(0.299)^{* *}$ \\
\hline \multirow[t]{2}{*}{ College $(=1)$} & 1.432 & 1.375 & 1.993 & 1.818 & 1.799 & 1.733 \\
\hline & $(0.201)^{* *}$ & $(0.195)^{* *}$ & $(0.486)^{* *}$ & $(0.454)^{* *}$ & $(0.339)^{* *}$ & $(0.331)^{* *}$ \\
\hline \multirow[t]{2}{*}{ Graduate School (=1) } & 1.864 & 1.805 & 2.472 & 2.291 & 2.358 & 2.291 \\
\hline & $(0.203)^{* *}$ & $(0.198)^{* *}$ & $(0.497)^{* *}$ & $(0.472)^{* *}$ & $(0.331)^{* *}$ & $(0.325)^{* *}$ \\
\hline \multirow[t]{2}{*}{ Attends religious services } & 1.588 & 1.505 & 1.991 & 1.802 & 1.424 & 1.343 \\
\hline & $(0.081)^{* *}$ & $(0.075)^{* *}$ & $(0.181)^{* *}$ & $(0.156)^{* *}$ & $(0.131)^{* *}$ & $(0.122)^{* *}$ \\
\hline Intercept & -7.752 & & -6.467 & & -8.482 & \\
\hline & $(0.842)^{* *}$ & & $(1.943)^{* *}$ & & $(1.394)^{* *}$ & \\
\hline $\begin{array}{l}\text { Average treatment effect ( } \\
\text { give) }\end{array}$ & 1.052 & & 1.074 & & 0.990 & \\
\hline & $(0.086)^{* *}$ & & $(0.206)^{* *}$ & & $(0.138)^{* *}$ & \\
\hline Average treatment effect 0 & & & & & & \\
\hline treated (Asked to give) & 1.039 & & 1.064 & & 0.979 & \\
\hline & $(0.081)^{* *}$ & & $(0.185)^{* *}$ & & $(0.131)^{* *}$ & \\
\hline$\sigma$ & 2.292 & & 2.587 & & 2.222 & \\
\hline & $(0.043)^{* *}$ & & $(0.103)^{* *}$ & & $(0.069)^{* *}$ & \\
\hline Log-likelihood & -7858.170 & & -1578.939 & & -3239.811 & \\
\hline Censored Observations & 450 & & 124 & & 170 & \\
\hline Number of Observations & 3712 & & 773 & & 1356 & \\
\hline
\end{tabular}

Notes: Sample weights are used in all regressions. Robust standard errors are reported in parenthesis. The $\operatorname{sign} *$ indicates that the variable is significant at $5 \%$ significance level. The sign $* *$ indicates that the variable is significant at $1 \%$ significance level. 
Table 6. Robustness checks for univariate models

\begin{tabular}{|c|c|c|c|c|c|c|c|c|}
\hline \multirow[b]{2}{*}{ Additional explanatory variables } & \multicolumn{4}{|c|}{ Probit model: The probability of giving } & \multicolumn{4}{|c|}{$\begin{array}{c}\text { Tobit model: Total amount of charitable } \\
\text { contributions }\end{array}$} \\
\hline & $\begin{array}{l}\text { Number of } \\
\text { Obs. }\end{array}$ & $\begin{array}{l}\text { Coefficient on } \\
\text { asked to give }\end{array}$ & ATE & ATT & $\begin{array}{l}\text { Number of } \\
\text { Obs. }\end{array}$ & $\begin{array}{l}\text { Coefficient on } \\
\text { asked to give }\end{array}$ & ATE & ATT \\
\hline \multicolumn{9}{|l|}{ Full Sample } \\
\hline 1. Base Mbdel & 4093 & $\begin{array}{c}0.711 \\
(0.073)\end{array}$ & $\begin{array}{c}0.082 \\
(0.008)\end{array}$ & $\begin{array}{c}0.068 \\
(0.007)\end{array}$ & 3712 & $\begin{array}{c}1.055 \\
(0.087)\end{array}$ & $\begin{array}{c}1.052 \\
(0.086)\end{array}$ & $\begin{array}{r}1.039 \\
(0.081)\end{array}$ \\
\hline $\begin{array}{l}\text { 2. Dummy variables: vote, } \\
\text { homeowner, born in USA }\end{array}$ & 4093 & $\begin{array}{c}0.670 \\
(0.073)\end{array}$ & $\begin{array}{c}0.075 \\
(0.008)\end{array}$ & $\begin{array}{c}0.061 \\
(0.007)\end{array}$ & 3712 & $\begin{array}{c}0.972 \\
(0.085)\end{array}$ & $\begin{array}{c}0.968 \\
(0.084)\end{array}$ & $\begin{array}{r}0.957 \\
(0.080)\end{array}$ \\
\hline 3. $\ln$ (Donations by others) & 3225 & $\begin{array}{c}0.671 \\
(0.081)\end{array}$ & $\begin{array}{c}0.080 \\
(0.007)\end{array}$ & $\begin{array}{c}0.052 \\
(0.006)\end{array}$ & 2927 & $\begin{array}{c}1.013 \\
(0.099)\end{array}$ & $\begin{array}{r}1.008 \\
(0.098)\end{array}$ & $\begin{array}{r}0.925 \\
(0.093)\end{array}$ \\
\hline 4. State Effects & 4010 & $\begin{array}{c}0.760 \\
(0.073)\end{array}$ & $\begin{array}{c}0.088 \\
(0.008)\end{array}$ & $\begin{array}{c}0.071 \\
(0.007)\end{array}$ & 3712 & $\begin{array}{c}1.071 \\
(0.087)\end{array}$ & $\begin{array}{c}1.065 \\
(0.086)\end{array}$ & $\begin{array}{r}1.050 \\
(0.081)\end{array}$ \\
\hline $\begin{array}{l}\text { 5. All of the variables in models } 1 \text {, } \\
2,3,4\end{array}$ & 3118 & $\begin{array}{c}0.675 \\
(0.083)\end{array}$ & $\begin{array}{c}0.076 \\
(0.007)\end{array}$ & $\begin{array}{c}0.046 \\
(0.006)\end{array}$ & 2927 & $\begin{array}{c}0.908 \\
(0.097)\end{array}$ & $\begin{array}{c}0.901 \\
(0.095)\end{array}$ & $\begin{array}{r}0.875 \\
(0.092)\end{array}$ \\
\hline \multicolumn{9}{|l|}{ Males } \\
\hline 6. Base Mbdel & 845 & $\begin{array}{c}0.552 \\
(0.142)\end{array}$ & $\begin{array}{c}0.070 \\
(0.018)\end{array}$ & $\begin{array}{c}0.061 \\
(0.016)\end{array}$ & 773 & $\begin{array}{c}1.077 \\
(0.212)\end{array}$ & $\begin{array}{r}1.074 \\
(0.206)\end{array}$ & $\begin{array}{r}1.064 \\
(0.185)\end{array}$ \\
\hline $\begin{array}{l}\text { 7. Dummy variables: vote, } \\
\text { homeowner, born in USA }\end{array}$ & 845 & $\begin{array}{c}0.494 \\
(0.139)\end{array}$ & $\begin{array}{c}0.060 \\
(0.017)\end{array}$ & $\begin{array}{c}0.052 \\
(0.015)\end{array}$ & 773 & $\begin{array}{c}0.933 \\
(0.207)\end{array}$ & $\begin{array}{c}0.929 \\
(0.201)\end{array}$ & $\begin{array}{r}0.922 \\
(0.185)\end{array}$ \\
\hline 8. $\ln$ (Donations by others) & 693 & $\begin{array}{c}0.584 \\
(0.153)\end{array}$ & $\begin{array}{c}0.080 \\
(0.016)\end{array}$ & $\begin{array}{c}0.056 \\
(0.015)\end{array}$ & 633 & $\begin{array}{c}1.312 \\
(0.235)\end{array}$ & $\begin{array}{c}1.306 \\
(0.226)\end{array}$ & $\begin{array}{r}1.066 \\
(0.204)\end{array}$ \\
\hline 9. State Effects & 707 & $\begin{array}{c}0.585 \\
(0.156)\end{array}$ & $\begin{array}{c}0.080 \\
(0.017)\end{array}$ & $\begin{array}{c}0.058 \\
(0.015)\end{array}$ & 773 & $\begin{array}{c}1.083 \\
(0.209)\end{array}$ & $\begin{array}{c}1.080 \\
(0.204)\end{array}$ & $\begin{array}{r}1.056 \\
(0.198)\end{array}$ \\
\hline $\begin{array}{l}\text { 10. All of the variables in models } 6 \text {, } \\
7,8,9\end{array}$ & 591 & $\begin{array}{c}0.594 \\
(0.172)\end{array}$ & $\begin{array}{c}0.079 \\
(0.016)\end{array}$ & $\begin{array}{c}0.046 \\
(0.014)\end{array}$ & 633 & $\begin{array}{c}1.146 \\
(0.228)\end{array}$ & $\begin{array}{c}1.120 \\
(0.235)\end{array}$ & $\begin{array}{r}1.047 \\
(0.276)\end{array}$ \\
\hline $\begin{array}{l}\text { Females } \\
\text { 11. Base Model }\end{array}$ & 1503 & $\begin{array}{c}0.627 \\
(0.117)\end{array}$ & $\begin{array}{c}0.064 \\
(0.012)\end{array}$ & $\begin{array}{c}0.052 \\
(0.010)\end{array}$ & 1356 & $\begin{array}{c}0.995 \\
(0.140)\end{array}$ & $\begin{array}{c}0.990 \\
(0.138)\end{array}$ & $\begin{array}{r}0.979 \\
(0.131)\end{array}$ \\
\hline $\begin{array}{l}\text { 12. Dummy variables: vote, } \\
\text { homeowner, born in USA }\end{array}$ & 1503 & $\begin{array}{c}0.587 \\
(0.119)\end{array}$ & $\begin{array}{c}0.058 \\
(0.012)\end{array}$ & $\begin{array}{c}0.045 \\
(0.010)\end{array}$ & 1356 & $\begin{array}{c}0.897 \\
(0.137)\end{array}$ & $\begin{array}{c}0.892 \\
(0.135)\end{array}$ & $\begin{array}{r}0.886 \\
(0.129)\end{array}$ \\
\hline 13. $\ln$ (Donations by others) & 1185 & $\begin{array}{c}0.578 \\
(0.128)\end{array}$ & $\begin{array}{c}0.063 \\
(0.011)\end{array}$ & $\begin{array}{c}0.040 \\
(0.010)\end{array}$ & 1066 & $\begin{array}{c}0.896 \\
(0.165)\end{array}$ & $\begin{array}{c}0.891 \\
(0.162)\end{array}$ & $\begin{array}{r}0.702 \\
(0.153)\end{array}$ \\
\hline 14. State Effects & 1419 & $\begin{array}{c}0.727 \\
(0.119)\end{array}$ & $\begin{array}{c}0.076 \\
(0.011)\end{array}$ & $\begin{array}{c}0.060 \\
(0.010)\end{array}$ & 1356 & $\begin{array}{c}1.003 \\
(0.141)\end{array}$ & $\begin{array}{c}1.001 \\
(0.138)\end{array}$ & $\begin{array}{r}0.987 \\
(0.131)\end{array}$ \\
\hline $\begin{array}{l}\text { 15. All of the variables in models } \\
11,12,13,14\end{array}$ & 1074 & $\begin{array}{c}0.668 \\
(0.137) \\
\end{array}$ & $\begin{array}{r}0.069 \\
(0.010) \\
\end{array}$ & $\begin{array}{r}0.038 \\
(0.008) \\
\end{array}$ & 1066 & $\begin{array}{c}0.791 \\
(0.159) \\
\end{array}$ & $\begin{array}{r}0.785 \\
(0.158) \\
\end{array}$ & $\begin{array}{r}0.762 \\
(0.154) \\
\end{array}$ \\
\hline
\end{tabular}

Notes: Sample weights are used in all regressions. Robust standard errors are reported in parenthesis. 
Table 7. ML estimates of the base bivariate probit models

\begin{tabular}{|c|c|c|c|c|c|c|}
\hline \multirow[b]{2}{*}{ Explanatory Variables } & \multicolumn{2}{|c|}{ Full Sample } & \multicolumn{2}{|c|}{ Males } & \multicolumn{2}{|c|}{ Females } \\
\hline & $\begin{array}{l}\text { The prob. of } \\
\text { giving }\end{array}$ & $\begin{array}{l}\text { The prob. of } \\
\text { being solicited }\end{array}$ & $\begin{array}{l}\text { The prob. of } \\
\text { giving }\end{array}$ & $\begin{array}{l}\text { The prob. of } \\
\text { being solicited }\end{array}$ & $\begin{array}{l}\text { The prob. of } \\
\text { giving }\end{array}$ & $\begin{array}{l}\text { The prob. of } \\
\text { being solicited }\end{array}$ \\
\hline Asked to give & $\begin{array}{c}1.799 \\
(0.197)^{* *}\end{array}$ & - & $\begin{array}{c}1.950 \\
(0.567)^{* *}\end{array}$ & - & $\begin{array}{c}1.762 \\
(0.363)^{* *}\end{array}$ & - \\
\hline $\ln$ (price) & $\begin{array}{c}-0.472 \\
(0.212)^{*}\end{array}$ & $\begin{array}{l}-0.106 \\
(0.130)\end{array}$ & $\begin{array}{c}0.220 \\
(0.497)\end{array}$ & $\begin{array}{c}-0.607 \\
(0.310)^{*}\end{array}$ & $\begin{array}{l}-0.505 \\
(0.383)\end{array}$ & $\begin{array}{c}0.056 \\
(0.230)\end{array}$ \\
\hline ln (household income) & $\begin{array}{l}0.095 \\
(0.053)\end{array}$ & $\begin{array}{c}0.219 \\
(0.036)^{* *}\end{array}$ & $\begin{array}{l}-0.163 \\
(0.091)\end{array}$ & $\begin{array}{c}0.271 \\
(0.077)^{* *}\end{array}$ & $\begin{array}{c}0.165 \\
(0.097)\end{array}$ & $\begin{array}{c}0.185 \\
(0.059)^{* *}\end{array}$ \\
\hline Age & $\begin{array}{l}-0.015 \\
(0.011)\end{array}$ & $\begin{array}{c}0.037 \\
(0.008)^{* *}\end{array}$ & $\begin{array}{c}0.001 \\
(0.022)\end{array}$ & $\begin{array}{c}0.024 \\
(0.016)\end{array}$ & $\begin{array}{l}-0.033 \\
(0.018)\end{array}$ & $\begin{array}{c}0.045 \\
(0.013)^{* *}\end{array}$ \\
\hline $\operatorname{Age}^{2}(\times 100)$ & $\begin{array}{c}0.018 \\
(0.010)\end{array}$ & $\begin{array}{l}-0.031 \\
(0.008)\end{array}$ & $\begin{array}{c}0.003 \\
(0.020)\end{array}$ & $\begin{array}{l}-0.023 \\
(0.015)\end{array}$ & $\begin{array}{c}0.030 \\
(0.016)\end{array}$ & $\begin{array}{c}-0.037 \\
(0.012)^{* *}\end{array}$ \\
\hline Family size & $\begin{array}{c}0.065 \\
(0.027)^{*}\end{array}$ & $\begin{array}{l}-0.016 \\
(0.018)\end{array}$ & $\begin{array}{c}0.110 \\
(0.056)^{*}\end{array}$ & $\begin{array}{l}-0.055 \\
(0.045)\end{array}$ & $\begin{array}{c}0.062 \\
(0.048)\end{array}$ & $\begin{array}{l}-0.007 \\
(0.033)\end{array}$ \\
\hline Employed & $\begin{array}{c}0.199 \\
(0.073)^{* *}\end{array}$ & $\begin{array}{l}-0.023 \\
(0.054)\end{array}$ & $\begin{array}{c}0.356 \\
(0.149)^{*}\end{array}$ & $\begin{array}{c}-0.297 \\
(0.136)^{*}\end{array}$ & $\begin{array}{c}0.093 \\
(0.131)\end{array}$ & $\begin{array}{c}0.167 \\
(0.088)\end{array}$ \\
\hline Married & $\begin{array}{l}-0.029 \\
(0.072)\end{array}$ & $\begin{array}{c}0.096 \\
(0.051)\end{array}$ & $\begin{array}{l}-0.135 \\
(0.154)\end{array}$ & $\begin{array}{c}0.198 \\
(0.123)\end{array}$ & $\begin{array}{l}-0.145 \\
(0.133)\end{array}$ & $\begin{array}{c}0.203 \\
(0.090)^{*}\end{array}$ \\
\hline White & $\begin{array}{c}0.132 \\
(0.120)\end{array}$ & $\begin{array}{c}0.291 \\
(0.092)^{* *}\end{array}$ & $\begin{array}{l}-0.357 \\
(0.228)\end{array}$ & $\begin{array}{c}0.356 \\
(0.179)^{*}\end{array}$ & $\begin{array}{c}0.362 \\
(0.220)\end{array}$ & $\begin{array}{c}0.341 \\
(0.165)^{*}\end{array}$ \\
\hline Black & $\begin{array}{c}0.015 \\
(0.137)\end{array}$ & $\begin{array}{c}0.176 \\
(0.111)\end{array}$ & $\begin{array}{l}-0.214 \\
(0.313)\end{array}$ & $\begin{array}{c}0.045 \\
(0.223)\end{array}$ & $\begin{array}{c}0.082 \\
(0.224)\end{array}$ & $\begin{array}{c}0.251 \\
(0.187)\end{array}$ \\
\hline Hispanic & $\begin{array}{c}0.073 \\
(0.110)\end{array}$ & $\begin{array}{c}-0.243 \\
(0.088)^{* *}\end{array}$ & $\begin{array}{c}0.181 \\
(0.232)\end{array}$ & $\begin{array}{l}-0.187 \\
(0.179)\end{array}$ & $\begin{array}{l}-0.113 \\
(0.177)\end{array}$ & $\begin{array}{l}-0.057 \\
(0.145)\end{array}$ \\
\hline Male & $\begin{array}{l}-0.035 \\
(0.061)\end{array}$ & $\begin{array}{l}-0.036 \\
(0.044)\end{array}$ & - & - & - & - \\
\hline High School (=1) & $\begin{array}{c}0.194 \\
(0.093)^{*}\end{array}$ & $\begin{array}{c}0.217 \\
(0.075)^{* *}\end{array}$ & $\begin{array}{c}0.368 \\
(0.236)\end{array}$ & $\begin{array}{l}-0.017 \\
(0.195)\end{array}$ & $\begin{array}{c}0.071 \\
(0.149)\end{array}$ & $\begin{array}{c}0.234 \\
(0.124)\end{array}$ \\
\hline Some College $(=1)$ & $\begin{array}{c}0.433 \\
(0.124)^{* *}\end{array}$ & $\begin{array}{c}0.405 \\
(0.080)^{* *}\end{array}$ & $\begin{array}{c}0.748 \\
(0.367)^{*}\end{array}$ & $\begin{array}{c}0.039 \\
(0.185)\end{array}$ & $\begin{array}{c}0.223 \\
(0.197)\end{array}$ & $\begin{array}{c}0.372 \\
(0.132)^{* *}\end{array}$ \\
\hline College (=1) & $\begin{array}{c}0.175 \\
(0.129)\end{array}$ & $\begin{array}{c}0.525 \\
(0.088)^{* *}\end{array}$ & $\begin{array}{c}0.503 \\
(0.353)\end{array}$ & $\begin{array}{c}0.155 \\
(0.199)\end{array}$ & $\begin{array}{c}0.025 \\
(0.212)\end{array}$ & $\begin{array}{c}0.508 \\
(0.152)^{* *}\end{array}$ \\
\hline Graduate School (=1) & $\begin{array}{c}0.317 \\
(0.173)\end{array}$ & $\begin{array}{c}0.755 \\
(0.099)^{* *}\end{array}$ & $\begin{array}{c}0.686 \\
(0.472)\end{array}$ & $\begin{array}{c}0.373 \\
(0.222)\end{array}$ & $\begin{array}{c}0.500 \\
(0.291)\end{array}$ & $\begin{array}{c}0.797 \\
(0.173)^{* *}\end{array}$ \\
\hline Attends religious services & $\begin{array}{c}0.447 \\
(0.083)^{* *}\end{array}$ & $\begin{array}{c}0.110 \\
(0.045)^{*}\end{array}$ & $\begin{array}{c}0.665 \\
(0.369)\end{array}$ & $\begin{array}{c}0.064 \\
(0.107)\end{array}$ & $\begin{array}{c}0.477 \\
(0.137)^{* *}\end{array}$ & $\begin{array}{c}0.100 \\
(0.074)\end{array}$ \\
\hline No. of charitable org./population (PCP) & - & $\begin{array}{c}136.076 \\
(41.138)^{* *}\end{array}$ & - & $\begin{array}{c}-0.457 \\
(123.548)\end{array}$ & - & $\begin{array}{c}188.991 \\
(63.066)^{* *}\end{array}$ \\
\hline Intercept & $\begin{array}{c}-1.182 \\
(0.603)^{*}\end{array}$ & $\begin{array}{c}-3.888 \\
(0.404)^{* *}\end{array}$ & $\begin{array}{c}0.900 \\
(1.067)\end{array}$ & $\begin{array}{c}-3.539 \\
(0.845)^{* *}\end{array}$ & $\begin{array}{l}-1.324 \\
(1.109)\end{array}$ & $\begin{array}{c}-3.929 \\
(0.669)^{* *}\end{array}$ \\
\hline Average treatment effect (Asked to give) & $\begin{array}{c}0.314 \\
(0.070)^{* *}\end{array}$ & & $\begin{array}{c}0.414 \\
(0.242)^{*}\end{array}$ & & $\begin{array}{c}0.298 \\
(0.128)^{*}\end{array}$ & \\
\hline $\begin{array}{l}\text { Average treatment effect on the treated } \\
\text { (Asked to give) }\end{array}$ & $\begin{array}{c}0.160 \\
(0.061)^{* *}\end{array}$ & & $\begin{array}{c}0.259 \\
(0.181)\end{array}$ & & $\begin{array}{c}0.114 \\
(0.098)^{*}\end{array}$ & \\
\hline$\rho$ & $\begin{array}{l}-0.700 \\
(0.114)\end{array}$ & & $\begin{array}{l}-0.892 \\
(0.287)\end{array}$ & & $\begin{array}{l}-0.714 \\
(0.207)\end{array}$ & \\
\hline Log-likelihood & -3490.166 & & -715.480 & & -1465.349 & \\
\hline Number of Observations & 4069 & & 841 & & 1493 & \\
\hline
\end{tabular}

Notes: Sample weights are used in all regressions. Robust standard errors are reported in parenthesis. The sign * indicates that the variable is significant at $5 \%$ significance level. The sign ** indicates that the variable is significant at $1 \%$ significance level. 
Table 8. Robustness checks for the bivariate probit models

\begin{tabular}{|c|c|c|c|c|c|c|c|}
\hline \multirow[b]{2}{*}{ Additional explanatory variables } & \multicolumn{6}{|c|}{ MLE estimates of bivariate probit model } & \multirow{2}{*}{$\begin{array}{c}\text { 2SLS } \\
\text { Coefficient on } \\
\text { asked to give }\end{array}$} \\
\hline & $\begin{array}{l}\text { Number of } \\
\text { Obs. }\end{array}$ & $\begin{array}{l}\text { Coefficient on } \\
\text { asked to give }\end{array}$ & ATE & ATT & $\rho$ & $\begin{array}{l}\text { Wald Test of } \\
\rho=0 \text { (p-value) }\end{array}$ & \\
\hline \multicolumn{8}{|l|}{ Full Sample } \\
\hline 1. Base model without instruments & 4093 & $\begin{array}{l}1.698 \\
(0.252)\end{array}$ & $\begin{array}{c}0.281 \\
(0.083)\end{array}$ & $\begin{array}{c}0.160 \\
(0.066)\end{array}$ & $\begin{array}{l}-0.638 \\
(0.153)\end{array}$ & $\begin{array}{l}8.538 \\
(0.004)\end{array}$ & - \\
\hline 2. Base model & 4069 & $\begin{array}{l}1.799 \\
(0.197)\end{array}$ & $\begin{array}{c}0.314 \\
(0.070)\end{array}$ & $\begin{array}{c}0.152 \\
(0.061)\end{array}$ & $\begin{array}{l}-0.700 \\
(0.114)\end{array}$ & $\begin{array}{l}14.974 \\
(0.000)\end{array}$ & $\begin{array}{l}0.210 \\
(0.184)\end{array}$ \\
\hline $\begin{array}{l}\text { 3. Dummy variables: vote, homeowner, } \\
\text { born in USA }\end{array}$ & 4069 & $\begin{array}{c}1.801 \\
(0.180)\end{array}$ & $\begin{array}{c}0.313 \\
(0.064)\end{array}$ & $\begin{array}{c}0.133 \\
(0.052)\end{array}$ & $\begin{array}{l}-0.722 \\
(0.101)\end{array}$ & $\begin{array}{l}18.726 \\
(0.000)\end{array}$ & $\begin{array}{c}0.219 \\
(0.188)\end{array}$ \\
\hline 4. $\ln$ (Donations by others) & 3205 & $\begin{array}{c}1.814 \\
(0.195)\end{array}$ & $\begin{array}{c}0.329 \\
(0.070)\end{array}$ & $\begin{array}{c}0.138 \\
(0.059)\end{array}$ & $\begin{array}{l}-0.726 \\
(0.107)\end{array}$ & $\begin{array}{l}16.605 \\
(0.000)\end{array}$ & $\begin{array}{c}0.354 \\
(0.310)\end{array}$ \\
\hline 5. State Effects & 4069 & $\begin{array}{c}1.731 \\
(0.219)\end{array}$ & $\begin{array}{c}0.271 \\
(0.070)\end{array}$ & $\begin{array}{c}0.160 \\
(0.053)\end{array}$ & $\begin{array}{l}-0.631 \\
(0.132)\end{array}$ & $\begin{array}{l}11.398 \\
(0.001)\end{array}$ & $\begin{array}{c}0.071 \\
(0.166)\end{array}$ \\
\hline $\begin{array}{l}\text { 6. All of the variables in models } 2,3,4 \text {, } \\
5\end{array}$ & 3205 & $\begin{array}{l}1.766 \\
(0.194)\end{array}$ & $\begin{array}{c}0.284 \\
(0.066)\end{array}$ & $\begin{array}{c}0.137 \\
(0.052)\end{array}$ & $\begin{array}{l}-0.694 \\
(0.109)\end{array}$ & $\begin{array}{l}16.704 \\
(0.000)\end{array}$ & $\begin{array}{c}0.270 \\
(0.264)\end{array}$ \\
\hline \multicolumn{8}{|l|}{ Males } \\
\hline 7. Base model without instruments & 845 & $\begin{array}{c}1.949 \\
(0.409)\end{array}$ & $\begin{array}{c}0.411 \\
(0.171)\end{array}$ & $\begin{array}{c}0.261 \\
(0.141)\end{array}$ & $\begin{array}{l}-0.889 \\
(0.205)\end{array}$ & $\begin{array}{c}2.095 \\
(0.148)\end{array}$ & - \\
\hline 8. Base model & 841 & $\begin{array}{c}1.950 \\
(0.567)\end{array}$ & $\begin{array}{c}0.414 \\
(0.242)\end{array}$ & $\begin{array}{c}0.259 \\
(0.181)\end{array}$ & $\begin{array}{l}-0.892 \\
(0.287)\end{array}$ & $\begin{array}{l}1.036 \\
(0.309)\end{array}$ & $\begin{array}{c}-0.711 \\
(1.123)\end{array}$ \\
\hline $\begin{array}{l}\text { 9. Dummy variables: vote, homeowner, } \\
\text { born in USA }\end{array}$ & 841 & $\begin{array}{c}1.942 \\
(0.346)\end{array}$ & $\begin{array}{c}0.413 \\
(0.145)\end{array}$ & $\begin{array}{c}0.239 \\
(0.109)\end{array}$ & $\begin{array}{l}-0.914 \\
(0.153)\end{array}$ & $\begin{array}{l}2.758 \\
(0.097)\end{array}$ & $\begin{array}{l}-0.673 \\
(1.010)\end{array}$ \\
\hline 10. $\ln$ (Donations by others) & 689 & $\begin{array}{c}2.108 \\
(0.348)\end{array}$ & $\begin{array}{c}0.493 \\
(0.143)\end{array}$ & $\begin{array}{c}0.335 \\
(0.108)\end{array}$ & $\begin{array}{l}-0.957 \\
(0.132)\end{array}$ & $\begin{array}{l}1.450 \\
(0.229)\end{array}$ & $\begin{array}{l}-0.248 \\
(0.797)\end{array}$ \\
\hline 11. State Effects & 841 & $\begin{array}{l}-0.198 \\
(0.657)\end{array}$ & $\begin{array}{l}-0.024 \\
(0.078)\end{array}$ & $\begin{array}{l}-0.022 \\
(0.026)\end{array}$ & $\begin{array}{c}0.470 \\
(0.349)\end{array}$ & $\begin{array}{l}1.300 \\
(0.254)\end{array}$ & $\begin{array}{l}-2.332 \\
(5.070)\end{array}$ \\
\hline $\begin{array}{l}\text { 12. All of the variables in models } 8,9 \text {, } \\
10,11\end{array}$ & 689 & $\begin{array}{c}1.977 \\
(0.317)\end{array}$ & $\begin{array}{c}0.399 \\
(0.129)\end{array}$ & $\begin{array}{c}0.240 \\
(0.101)\end{array}$ & $\begin{array}{l}-0.899 \\
(0.140)\end{array}$ & $\begin{array}{l}4.056 \\
(0.044)\end{array}$ & $\begin{array}{l}-0.664 \\
(2.032)\end{array}$ \\
\hline \multicolumn{8}{|l|}{ Females } \\
\hline 13. Base model without instruments & 1503 & $\begin{array}{c}1.426 \\
(0.769)\end{array}$ & $\begin{array}{c}0.196 \\
(0.203)\end{array}$ & $\begin{array}{c}0.119 \\
(0.129)\end{array}$ & $\begin{array}{l}-0.513 \\
(0.487)\end{array}$ & $\begin{array}{c}0.734 \\
(0.392)\end{array}$ & - \\
\hline 14. Base model & 1493 & $\begin{array}{c}1.762 \\
(0.363)\end{array}$ & $\begin{array}{c}0.298 \\
(0.128)\end{array}$ & $\begin{array}{c}0.114 \\
(0.098)\end{array}$ & $\begin{array}{l}-0.714 \\
(0.207)\end{array}$ & $\begin{array}{c}4.477 \\
(0.034)\end{array}$ & $\begin{array}{c}0.256 \\
(0.211)\end{array}$ \\
\hline $\begin{array}{l}\text { 15. Dummy variables: vote, homeowner, } \\
\text { born in USA }\end{array}$ & 1493 & $\begin{array}{c}1.717 \\
(0.327)\end{array}$ & $\begin{array}{c}0.276 \\
(0.111)\end{array}$ & $\begin{array}{c}0.106 \\
(0.079)\end{array}$ & $\begin{array}{l}-0.706 \\
(0.181)\end{array}$ & $\begin{array}{l}5.919 \\
(0.015)\end{array}$ & $\begin{array}{c}0.282 \\
(0.222)\end{array}$ \\
\hline 16. $\ln$ (Donations by others) & 1177 & $\begin{array}{c}1.864 \\
(0.262)\end{array}$ & $\begin{array}{c}0.359 \\
(0.099)\end{array}$ & $\begin{array}{c}0.186 \\
(0.094)\end{array}$ & $\begin{array}{l}-0.793 \\
(0.130)\end{array}$ & $\begin{array}{c}9.459 \\
(0.002)\end{array}$ & $\begin{array}{c}0.439 \\
(0.333)\end{array}$ \\
\hline 17. State Effects & 1493 & $\begin{array}{c}1.800 \\
(0.360)\end{array}$ & $\begin{array}{c}0.266 \\
(0.123)\end{array}$ & $\begin{array}{c}0.127 \\
(0.093)\end{array}$ & $\begin{array}{l}-0.685 \\
(0.206)\end{array}$ & $\begin{array}{c}4.657 \\
(0.031)\end{array}$ & $\begin{array}{c}0.263 \\
(0.220)\end{array}$ \\
\hline $\begin{array}{l}\text { 18. All of the variables in models } 14,15 \text {, } \\
16,17\end{array}$ & 1177 & $\begin{array}{l}1.871 \\
(0.278)\end{array}$ & $\begin{array}{c}0.327 \\
(0.108)\end{array}$ & $\begin{array}{c}0.164 \\
(0.090)\end{array}$ & $\begin{array}{l}-0.800 \\
(0.131)\end{array}$ & $\begin{array}{c}9.092 \\
(0.003)\end{array}$ & $\begin{array}{c}0.694 \\
(0.526)\end{array}$ \\
\hline
\end{tabular}

Notes: Sample weights are used in all regressions. Robust standard errors are reported in parenthesis. 
Table 9. ML estimates of the base endogenous tobit models

\begin{tabular}{|c|c|c|c|c|c|c|}
\hline \multirow[b]{2}{*}{ Explanatory Variables } & \multicolumn{2}{|c|}{ Full Sample } & \multicolumn{2}{|c|}{ Males } & \multicolumn{2}{|c|}{ Females } \\
\hline & $\begin{array}{c}\text { The contribution } \\
\text { amount }\end{array}$ & $\begin{array}{l}\text { The prob. of } \\
\text { being } \\
\text { solicited }\end{array}$ & $\begin{array}{c}\text { The contribution } \\
\text { amount }\end{array}$ & $\begin{array}{l}\text { The prob. of } \\
\text { being } \\
\text { solicited }\end{array}$ & $\begin{array}{c}\text { The contribution } \\
\text { amount }\end{array}$ & $\begin{array}{c}\text { The prob. of } \\
\text { being } \\
\text { solicited }\end{array}$ \\
\hline Asked to give & $\begin{array}{c}3.890 \\
(0.169)^{* *}\end{array}$ & - & $\begin{array}{l}-1.320 \\
(0.851)\end{array}$ & - & $\begin{array}{c}3.927 \\
(0.258)^{* *}\end{array}$ & - \\
\hline $\ln$ (price) & $\begin{array}{c}-2.323 \\
(0.478)^{* *}\end{array}$ & $\begin{array}{c}0.245 \\
(0.211)\end{array}$ & $\begin{array}{l}-1.193 \\
(1.076)\end{array}$ & $\begin{array}{l}-0.620 \\
(0.381)\end{array}$ & $\begin{array}{l}-1.028 \\
(0.850)\end{array}$ & $\begin{array}{l}-0.134 \\
(0.404)\end{array}$ \\
\hline ln (household income) & $\begin{array}{c}0.761 \\
(0.125)^{* *}\end{array}$ & $\begin{array}{c}0.211 \\
(0.056)^{* *}\end{array}$ & $\begin{array}{c}0.781 \\
(0.288)^{* *}\end{array}$ & $\begin{array}{c}0.332 \\
(0.112)^{* *}\end{array}$ & $\begin{array}{c}0.994 \\
(0.225)^{* *}\end{array}$ & $\begin{array}{c}0.087 \\
(0.101)\end{array}$ \\
\hline Age & $\begin{array}{c}0.015 \\
(0.030)\end{array}$ & $\begin{array}{c}0.035 \\
(0.013)^{* *}\end{array}$ & $\begin{array}{c}0.128 \\
(0.056)^{*}\end{array}$ & $\begin{array}{c}0.026 \\
(0.022)\end{array}$ & $\begin{array}{c}0.028 \\
(0.043)\end{array}$ & $\begin{array}{c}0.041 \\
(0.021)^{*}\end{array}$ \\
\hline $\operatorname{Age}^{2}(\times 100)$ & $\begin{array}{c}0.001 \\
(0.029)\end{array}$ & $\begin{array}{c}-0.029 \\
(0.013)^{*}\end{array}$ & $\begin{array}{l}-0.093 \\
(0.056)\end{array}$ & $\begin{array}{l}-0.024 \\
(0.022)\end{array}$ & $\begin{array}{l}-0.012 \\
(0.040)\end{array}$ & $\begin{array}{l}-0.034 \\
(0.020)\end{array}$ \\
\hline Family size & $\begin{array}{c}0.019 \\
(0.049)\end{array}$ & $\begin{array}{c}0.014 \\
(0.027)\end{array}$ & $\begin{array}{c}0.071 \\
(0.176)\end{array}$ & $\begin{array}{l}-0.077 \\
(0.064)\end{array}$ & $\begin{array}{c}0.262 \\
(0.102)^{*}\end{array}$ & $\begin{array}{l}-0.065 \\
(0.048)\end{array}$ \\
\hline Employed & $\begin{array}{c}0.094 \\
(0.181)\end{array}$ & $\begin{array}{c}0.051 \\
(0.084)\end{array}$ & $\begin{array}{c}0.207 \\
(0.487)\end{array}$ & $\begin{array}{l}-0.263 \\
(0.177)\end{array}$ & $\begin{array}{c}0.127 \\
(0.315)\end{array}$ & $\begin{array}{c}0.204 \\
(0.149)\end{array}$ \\
\hline Married & $\begin{array}{c}0.080 \\
(0.196)\end{array}$ & $\begin{array}{c}0.099 \\
(0.084)\end{array}$ & $\begin{array}{c}0.220 \\
(0.487)\end{array}$ & $\begin{array}{c}0.171 \\
(0.167)\end{array}$ & $\begin{array}{l}-0.659 \\
(0.365)\end{array}$ & $\begin{array}{c}0.447 \\
(0.170)^{*}\end{array}$ \\
\hline White & $\begin{array}{c}0.110 \\
(0.276)\end{array}$ & $\begin{array}{c}0.525 \\
(0.129)^{* *}\end{array}$ & $\begin{array}{c}0.186 \\
(0.642)\end{array}$ & $\begin{array}{c}0.282 \\
(0.243)\end{array}$ & $\begin{array}{c}0.452 \\
(0.480)\end{array}$ & $\begin{array}{c}0.579 \\
(0.253)^{*}\end{array}$ \\
\hline Black & $\begin{array}{l}-0.461 \\
(0.324)\end{array}$ & $\begin{array}{c}0.453 \\
(0.160)^{* *}\end{array}$ & $\begin{array}{l}-0.347 \\
(0.801)\end{array}$ & $\begin{array}{l}-0.178 \\
(0.299)\end{array}$ & $\begin{array}{l}-0.377 \\
(0.570)\end{array}$ & $\begin{array}{c}0.619 \\
(0.294)^{*}\end{array}$ \\
\hline Hispanic & $\begin{array}{c}0.010 \\
(0.286)\end{array}$ & $\begin{array}{l}-0.308 \\
(0.125)^{*}\end{array}$ & $\begin{array}{l}-0.478 \\
(0.561)\end{array}$ & $\begin{array}{l}-0.266 \\
(0.238)\end{array}$ & $\begin{array}{l}-0.385 \\
(0.455)\end{array}$ & $\begin{array}{l}-0.009 \\
(0.219)\end{array}$ \\
\hline Male & $\begin{array}{l}-0.228 \\
(0.157)\end{array}$ & $\begin{array}{c}0.082 \\
(0.072)\end{array}$ & - & - & - & - \\
\hline High School $(=1)$ & $\begin{array}{c}0.732 \\
(0.252)^{* *}\end{array}$ & $\begin{array}{c}0.346 \\
(0.115)^{* *}\end{array}$ & $\begin{array}{c}0.528 \\
(0.529)\end{array}$ & $\begin{array}{l}-0.160 \\
(0.259)\end{array}$ & $\begin{array}{c}0.955 \\
(0.415)^{*}\end{array}$ & $\begin{array}{c}0.528 \\
(0.202)^{* *}\end{array}$ \\
\hline Some College $(=1)$ & $\begin{array}{c}1.042 \\
(0.286)^{* *}\end{array}$ & $\begin{array}{c}0.629 \\
(0.130)^{* *}\end{array}$ & $\begin{array}{c}2.497 \\
(0.484)^{* *}\end{array}$ & $\begin{array}{c}0.160 \\
(0.234)\end{array}$ & $\begin{array}{c}1.311 \\
(0.477)^{* *}\end{array}$ & $\begin{array}{c}0.670 \\
(0.225)^{* *}\end{array}$ \\
\hline College $(=1)$ & $\begin{array}{c}1.248 \\
(0.335)^{* *}\end{array}$ & $\begin{array}{c}0.596 \\
(0.144)^{* *}\end{array}$ & $\begin{array}{c}2.183 \\
(0.575)^{* *}\end{array}$ & $\begin{array}{c}0.146 \\
(0.253)\end{array}$ & $\begin{array}{c}1.069 \\
(0.593)\end{array}$ & $\begin{array}{c}0.848 \\
(0.274)^{* *}\end{array}$ \\
\hline Graduate School (=1) & $\begin{array}{c}1.946 \\
(0.381)^{* *}\end{array}$ & $\begin{array}{c}0.674 \\
(0.163)^{* *}\end{array}$ & $\begin{array}{c}3.059 \\
(0.770)^{* *}\end{array}$ & $\begin{array}{c}0.413 \\
(0.291)\end{array}$ & $\begin{array}{c}2.565 \\
(0.524)^{* *}\end{array}$ & $\begin{array}{c}0.682 \\
(0.258)^{* *}\end{array}$ \\
\hline Attends religious services & $\begin{array}{c}1.677 \\
(0.186)^{* *}\end{array}$ & $\begin{array}{c}0.102 \\
(0.078)\end{array}$ & $\begin{array}{c}3.804 \\
(0.536)^{* *}\end{array}$ & $\begin{array}{c}0.476 \\
(0.221)^{*}\end{array}$ & $\begin{array}{c}1.744 \\
(0.278)^{* *}\end{array}$ & $\begin{array}{c}0.015 \\
(0.131)\end{array}$ \\
\hline No. of charitable org./population (PCP) & - & $\begin{array}{l}102.087 \\
(51.82)^{*}\end{array}$ & - & $\begin{array}{l}142.722 \\
(88.743)\end{array}$ & - & $\begin{array}{c}229.852 \\
(81.178)^{* *}\end{array}$ \\
\hline Intercept & $\begin{array}{c}-9.701 \\
(1.521)^{* *}\end{array}$ & $\begin{array}{c}-3.286 \\
(0.654)^{* *}\end{array}$ & $\begin{array}{c}-12.951 \\
(3.045)^{* *}\end{array}$ & $\begin{array}{c}-5.209 \\
(1.432)^{* *}\end{array}$ & $\begin{array}{c}-12.783 \\
(2.559)^{* *}\end{array}$ & $\begin{array}{c}-2.474 \\
(1.153)^{*}\end{array}$ \\
\hline Average treatment effect (Asked to give) & $\begin{array}{c}3.342 \\
(0.172)^{* *}\end{array}$ & & $\begin{array}{l}-0.952 \\
(0.801)\end{array}$ & & $\begin{array}{c}3.438 \\
(0.273)^{* *}\end{array}$ & \\
\hline $\begin{array}{l}\text { Average treatment effect on the treated } \\
\text { (Asked to give) }\end{array}$ & $\begin{array}{c}2.269 \\
(0.315)^{* *}\end{array}$ & & $\begin{array}{l}-0.524 \\
(0.478)\end{array}$ & & $\begin{array}{c}2.322 \\
(0.524)^{* *}\end{array}$ & \\
\hline$\varphi$ & $\begin{array}{l}-0.112 \\
(0.009)\end{array}$ & & $\begin{array}{c}0.048 \\
(0.014)\end{array}$ & & $\begin{array}{l}-0.139 \\
(0.017)\end{array}$ & \\
\hline$\sigma$ & $\begin{array}{c}3.472 \\
(0.092)\end{array}$ & & $\begin{array}{c}4.896 \\
(0.391)\end{array}$ & & $\begin{array}{c}3.166 \\
(0.156)\end{array}$ & \\
\hline $\begin{array}{l}\text { Log-likelihood } \\
\text { Number of Observations }\end{array}$ & $\begin{array}{c}-11745.392 \\
3694 \\
\end{array}$ & & $\begin{array}{c}-2375.867 \\
770 \\
\end{array}$ & & $\begin{array}{c}-4801.3312 \\
1349 \\
\end{array}$ & \\
\hline
\end{tabular}

Notes: Sample weights are used in all regressions. Robust standard errors are reported in parenthesis. The sign * indicates that the variable is significant at $5 \%$ significance level. The sign ** indicates that the variable is significant at $1 \%$ significance level. 
Table 10. Robustness checks for the endogenous tobit models

\begin{tabular}{|c|c|c|c|c|c|c|}
\hline \multirow[b]{2}{*}{ Additional explanatory variables } & \multicolumn{6}{|c|}{ MLE estimates of the endogenous tobit model } \\
\hline & $\begin{array}{l}\text { Number of } \\
\text { Obs. }\end{array}$ & $\begin{array}{l}\text { Coefficient on } \\
\text { asked to give }\end{array}$ & ATE & $\mathrm{ATT}$ & $\varphi$ & $\begin{array}{l}\text { Wald Test of } \\
\varphi=0 \text { (p-value) }\end{array}$ \\
\hline \multicolumn{7}{|l|}{ Full Sample } \\
\hline 1. Base model without instruments & 3712 & $\begin{array}{c}3.906 \\
(0.167)\end{array}$ & $\begin{array}{c}3.348 \\
(0.174)\end{array}$ & $\begin{array}{c}2.278 \\
(0.316)\end{array}$ & $\begin{array}{l}-0.111 \\
(0.008)\end{array}$ & $\begin{array}{l}178.55 \\
(0.000)\end{array}$ \\
\hline 2. Base model & 3694 & $\begin{array}{c}3.890 \\
(0.169)\end{array}$ & $\begin{array}{c}3.342 \\
(0.172)\end{array}$ & $\begin{array}{c}2.269 \\
(0.315)\end{array}$ & $\begin{array}{l}-0.112 \\
(0.009)\end{array}$ & $\begin{array}{l}162.09 \\
(0.000)\end{array}$ \\
\hline $\begin{array}{l}\text { 3. Dummy variables: vote, homeowner, } \\
\text { born in USA }\end{array}$ & 3694 & $\begin{array}{c}3.721 \\
(0.170)\end{array}$ & $\begin{array}{c}3.220 \\
(0.161)\end{array}$ & $\begin{array}{c}2.170 \\
(0.301)\end{array}$ & $\begin{array}{l}-0.113 \\
(0.008)\end{array}$ & $\begin{array}{l}200.39 \\
(0.000)\end{array}$ \\
\hline 4. $\ln$ (Donations by others) & 2913 & $\begin{array}{c}3.888 \\
(0.192)\end{array}$ & $\begin{array}{c}3.358 \\
(0.190)\end{array}$ & $\begin{array}{c}2.303 \\
(0.353)\end{array}$ & $\begin{array}{l}-0.116 \\
(0.010)\end{array}$ & $\begin{array}{l}126.95 \\
(0.000)\end{array}$ \\
\hline 5. State Effects & 3694 & $\begin{array}{c}4.034 \\
(0.165)\end{array}$ & $\begin{array}{c}3.475 \\
(0.175)\end{array}$ & $\begin{array}{c}2.353 \\
(0.362)\end{array}$ & $\begin{array}{l}-0.115 \\
(0.010)\end{array}$ & $\begin{array}{l}142.48 \\
(0.000)\end{array}$ \\
\hline 6. All of the variables in models $2,3,4$ & 2913 & $\begin{array}{c}3.860 \\
(0.188)\end{array}$ & $\begin{array}{c}3.371 \\
(0.196)\end{array}$ & $\begin{array}{c}2.285 \\
(0.360)\end{array}$ & $\begin{array}{l}-0.121 \\
(0.012)\end{array}$ & $\begin{array}{l}108.49 \\
(0.000)\end{array}$ \\
\hline \multicolumn{7}{|l|}{ Males } \\
\hline 7. Base model without instruments & 773 & $\begin{array}{c}2.802 \\
(0.859)\end{array}$ & $\begin{array}{c}2.122 \\
(0.752)\end{array}$ & $\begin{array}{c}1.509 \\
(0.690)\end{array}$ & $\begin{array}{c}-0.041 \\
(0.023)\end{array}$ & $\begin{array}{c}2.98 \\
(0.084)\end{array}$ \\
\hline 8. Base model & 770 & $\begin{array}{l}-1.320 \\
(0.851)\end{array}$ & $\begin{array}{l}-0.952 \\
(0.801)\end{array}$ & $\begin{array}{l}-0.524 \\
(0.478)\end{array}$ & $\begin{array}{c}0.048 \\
(0.014)\end{array}$ & $\begin{array}{c}11.34 \\
(0.001)\end{array}$ \\
\hline $\begin{array}{l}\text { 9. Dummy variables: vote, homeowner, } \\
\text { born in USA }\end{array}$ & 770 & $\begin{array}{l}-1.889 \\
(0.587)\end{array}$ & $\begin{array}{l}-1.355 \\
(0.579)\end{array}$ & $\begin{array}{l}-0.726 \\
(0.601)\end{array}$ & $\begin{array}{c}0.055 \\
(0.011)\end{array}$ & $\begin{array}{c}26.53 \\
(0.000)\end{array}$ \\
\hline 10. $\ln$ (Donations by others) & 630 & $\begin{array}{l}-1.653 \\
(0.571)\end{array}$ & $\begin{array}{l}-1.128 \\
(0.552)\end{array}$ & $\begin{array}{l}-0.607 \\
(0.509)\end{array}$ & $\begin{array}{c}0.054 \\
(0.011)\end{array}$ & $\begin{array}{c}22.47 \\
(0.000)\end{array}$ \\
\hline 11. State Effects & 770 & $\begin{array}{c}3.610 \\
(0.533)\end{array}$ & $\begin{array}{c}2.798 \\
(0.457)\end{array}$ & $\begin{array}{c}1.964 \\
(0.637)\end{array}$ & $\begin{array}{c}-0.062 \\
(0.019)\end{array}$ & $\begin{array}{c}11.01 \\
(0.001)\end{array}$ \\
\hline 12. All of the variables in models $2,3,4$ & 630 & $\begin{array}{c}3.894 \\
(0.534)\end{array}$ & $\begin{array}{c}3.029 \\
(0.544)\end{array}$ & $\begin{array}{c}2.131 \\
(0.847)\end{array}$ & $\begin{array}{c}-0.068 \\
(0.024)\end{array}$ & $\begin{array}{c}8.27 \\
(0.004)\end{array}$ \\
\hline \multicolumn{7}{|l|}{ Females } \\
\hline 13. Base model without instruments & 1356 & $\begin{array}{c}3.894 \\
(0.257)\end{array}$ & $\begin{array}{c}3.405 \\
(0.272)\end{array}$ & $\begin{array}{c}2.302 \\
(0.519)\end{array}$ & $\begin{array}{c}-0.136 \\
(0.017)\end{array}$ & $\begin{array}{c}61.04 \\
(0.000)\end{array}$ \\
\hline 14. Base model & 1349 & $\begin{array}{c}3.927 \\
(0.258)\end{array}$ & $\begin{array}{c}3.438 \\
(0.273)\end{array}$ & $\begin{array}{c}2.322 \\
(0.524)\end{array}$ & $\begin{array}{l}-0.139 \\
(0.017)\end{array}$ & $\begin{array}{c}64.58 \\
(0.000)\end{array}$ \\
\hline $\begin{array}{l}15 . \text { Dummy variables: vote, homeowner, } \\
\text { born in USA }\end{array}$ & 1349 & $\begin{array}{c}3.709 \\
(0.289)\end{array}$ & $\begin{array}{c}3.293 \\
(0.249)\end{array}$ & $\begin{array}{c}2.193 \\
(0.494)\end{array}$ & $\begin{array}{l}-0.148 \\
(0.019)\end{array}$ & $\begin{array}{c}59.44 \\
(0.000)\end{array}$ \\
\hline 16. $\ln$ (Donations by others) & 1061 & $\begin{array}{c}3.815 \\
(0.319)\end{array}$ & $\begin{array}{c}3.314 \\
(0.309)\end{array}$ & $\begin{array}{c}2.312 \\
(0.570)\end{array}$ & $\begin{array}{l}-0.125 \\
(0.021)\end{array}$ & $\begin{array}{c}36.78 \\
(0.000)\end{array}$ \\
\hline 17. State Effects & 1349 & $\begin{array}{c}4.320 \\
(0.255)\end{array}$ & $\begin{array}{c}3.338 \\
(0.414)\end{array}$ & $\begin{array}{c}2.527 \\
(0.572)\end{array}$ & $\begin{array}{c}-0.136 \\
(0.020)\end{array}$ & $\begin{array}{c}44.87 \\
(0.000)\end{array}$ \\
\hline 18. All of the variables in models $2,3,4$ & 1061 & $\begin{array}{c}3.935 \\
(0.309) \\
\end{array}$ & $\begin{array}{c}3.481 \\
(0.310) \\
\end{array}$ & $\begin{array}{c}2.378 \\
(0.587) \\
\end{array}$ & $\begin{array}{l}-0.141 \\
(0.023)\end{array}$ & $\begin{array}{r}37.42 \\
(0.000) \\
\end{array}$ \\
\hline
\end{tabular}

Notes: Sample weights are used in all regressions. Robust standard errors are reported in parenthesis. 
Table 11. Tests for the validity of the instrumental variables

\begin{tabular}{|c|c|c|c|c|c|}
\hline \multirow[b]{2}{*}{ Instruments } & \multicolumn{3}{|c|}{$\begin{array}{l}\text { Models with endogenous probability of being } \\
\text { solicited }\end{array}$} & \multicolumn{2}{|c|}{ Tests of instruments in linear 2SLS models } \\
\hline & $\begin{array}{l}\text { Coefficient on } \\
\text { asked to give }\end{array}$ & $\rho \operatorname{or} \varphi$ & $\begin{array}{l}\text { Wald Test of } \rho=0 \\
\text { or } \varphi=0 \text { (p-value) }\end{array}$ & $\begin{array}{l}\text { F-test of excluded } \\
\text { instruments (p-value) }\end{array}$ & $\begin{array}{l}\text { overidentification } \\
\text { test (p-value) }\end{array}$ \\
\hline \multicolumn{6}{|l|}{ The prob. of giving } \\
\hline 1. PCP & $\begin{array}{c}1.799 \\
(0.197)\end{array}$ & $\begin{array}{l}-0.700 \\
(0.114)\end{array}$ & $\begin{array}{l}14.974 \\
(0.000)\end{array}$ & $\begin{array}{c}9.15 \\
(0.003)\end{array}$ & - \\
\hline 2. $\ln$ (fundraising exp./pop) & $\begin{array}{l}1.741 \\
(0.261)\end{array}$ & $\begin{array}{l}-0.660 \\
(0.158)\end{array}$ & $\begin{array}{c}8.053 \\
(0.005)\end{array}$ & $\begin{array}{c}12.46 \\
(0.000)\end{array}$ & - \\
\hline 3. PCP, ln (fundraising exp. /pop) & $\begin{array}{c}1.792 \\
(0.222)\end{array}$ & $\begin{array}{l}-0.693 \\
(0.131)\end{array}$ & $\begin{array}{l}11.536 \\
(0.001)\end{array}$ & $\begin{array}{c}6.70 \\
(0.001)\end{array}$ & $\begin{array}{c}1.987 \\
(0.168)\end{array}$ \\
\hline 4. Belong to any org. & $\begin{array}{c}1.978 \\
(0.183)\end{array}$ & $\begin{array}{l}-0.762 \\
(0.092)\end{array}$ & $\begin{array}{l}20.931 \\
(0.000)\end{array}$ & $\begin{array}{c}49.40 \\
(0.000)\end{array}$ & - \\
\hline 5. PCP, Belong to any org. & $\begin{array}{c}2.045 \\
(0.159)\end{array}$ & $\begin{array}{l}-0.797 \\
(0.075)\end{array}$ & $\begin{array}{l}28.294 \\
(0.000)\end{array}$ & $\begin{array}{c}26.95 \\
(0.000)\end{array}$ & $\begin{array}{c}0.009 \\
(0.925)\end{array}$ \\
\hline $\begin{array}{l}\text { 6. ln (fundraising exp./pop), Belong to } \\
\text { any org. }\end{array}$ & $\begin{array}{c}2.049 \\
(0.180)\end{array}$ & $\begin{array}{l}-0.790 \\
(0.087)\end{array}$ & $\begin{array}{l}21.638 \\
(0.000)\end{array}$ & $\begin{array}{c}27.17 \\
(0.000)\end{array}$ & $\begin{array}{c}3.448 \\
(0.063)\end{array}$ \\
\hline $\begin{array}{l}\text { 7. PCP, } \ln \text { (fundraising exp./pop), } \\
\text { Belong to any org. }\end{array}$ & $\begin{array}{c}2.078 \\
(0.173)\end{array}$ & $\begin{array}{l}-0.806 \\
(0.080)\end{array}$ & $\begin{array}{l}23.713 \\
(0.000)\end{array}$ & $\begin{array}{c}18.26 \\
(0.000)\end{array}$ & $\begin{array}{c}5.681 \\
(0.058)\end{array}$ \\
\hline $\ln$ (1+amount of contributions) & & & & & \\
\hline 8. PCP & $\begin{array}{c}3.890 \\
(0.169)\end{array}$ & $\begin{array}{l}-0.112 \\
(0.009)\end{array}$ & $\begin{array}{l}162.09 \\
(0.000)\end{array}$ & $\begin{array}{c}10.68 \\
(0.001)\end{array}$ & - \\
\hline 9. $\ln$ (fundraising exp./pop) & $\begin{array}{c}3.844 \\
(0.172)\end{array}$ & $\begin{array}{l}-0.112 \\
(0.008)\end{array}$ & $\begin{array}{l}171.48 \\
(0.000)\end{array}$ & $\begin{array}{c}14.21 \\
(0.000)\end{array}$ & - \\
\hline 10. PCP, ln (fundraising exp. /pop) & $\begin{array}{c}3.843 \\
(0.173)\end{array}$ & $\begin{array}{l}-0.112 \\
(0.009)\end{array}$ & $\begin{array}{l}162.79 \\
(0.000)\end{array}$ & $\begin{array}{c}8.08 \\
(0.000)\end{array}$ & $\begin{array}{c}0.006 \\
(0.937)\end{array}$ \\
\hline 11. Belong to any org. & $\begin{array}{c}4.206 \\
(0.173)\end{array}$ & $\begin{array}{l}-0.136 \\
(0.008)\end{array}$ & $\begin{array}{l}294.06 \\
(0.000)\end{array}$ & $\begin{array}{c}42.72 \\
(0.000)\end{array}$ & - \\
\hline 12. PCP, Belong to any org. & $\begin{array}{c}4.189 \\
(0.174)\end{array}$ & $\begin{array}{l}-0.138 \\
(0.007)\end{array}$ & $\begin{array}{l}378.12 \\
(0.000)\end{array}$ & $\begin{array}{c}24.17 \\
(0.000)\end{array}$ & $\begin{array}{c}2.618 \\
(0.106)\end{array}$ \\
\hline $\begin{array}{l}\text { 13. ln (fundraising exp./pop), Belong } \\
\text { to any org. }\end{array}$ & $\begin{array}{c}4.172 \\
(0.178)\end{array}$ & $\begin{array}{l}-0.139 \\
(0.008)\end{array}$ & $\begin{array}{l}287.12 \\
(0.000)\end{array}$ & $\begin{array}{c}25.04 \\
(0.000)\end{array}$ & $\begin{array}{c}6.440 \\
(0.011)\end{array}$ \\
\hline $\begin{array}{l}\text { 14. PCP, ln (fundraising exp./pop), } \\
\text { Belong to any org. }\end{array}$ & $\begin{array}{c}4.172 \\
(0.177)\end{array}$ & $\begin{array}{l}-0.140 \\
(0.008)\end{array}$ & $\begin{array}{l}308.53 \\
(0.000)\end{array}$ & $\begin{array}{c}16.94 \\
(0.000)\end{array}$ & $\begin{array}{c}6.448 \\
(0.040)\end{array}$ \\
\hline
\end{tabular}

Notes: Sample weights are used in all regressions. Robust standard errors are reported in parenthesis. 


\section{Figures}

Figure 1. The propensity to give and amount of charitable contributions by age

A. Full sample

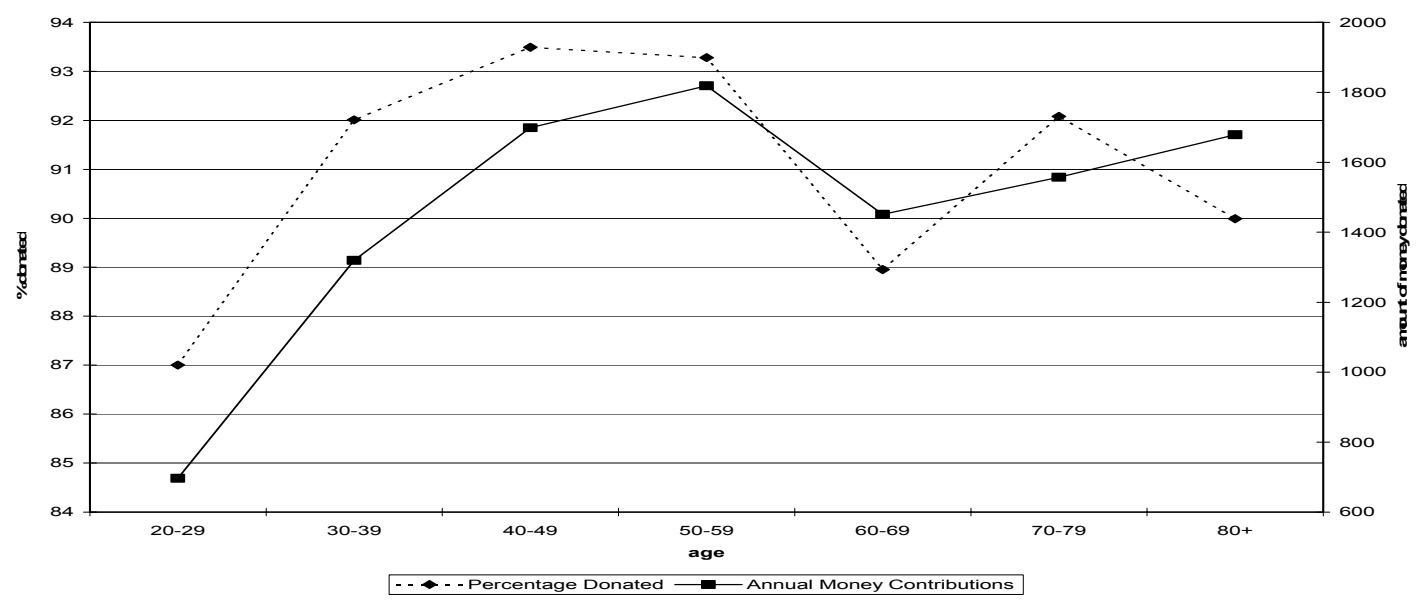

B. The propensity to give by sex

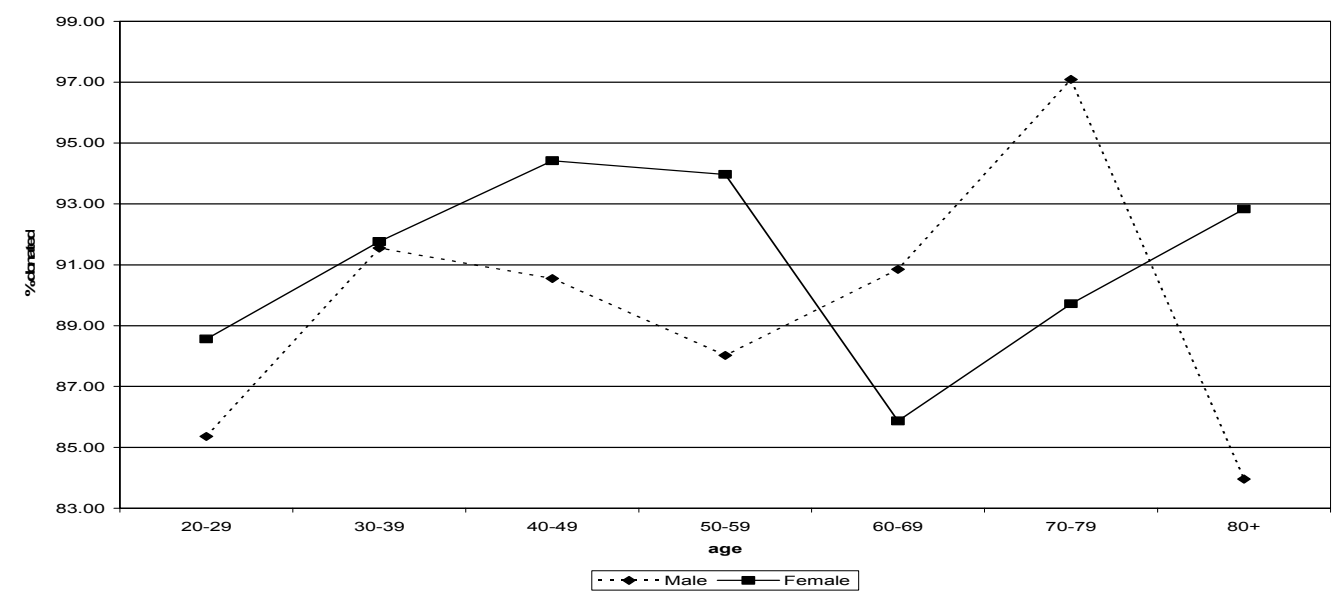

C. The amount of charitable contributions by sex

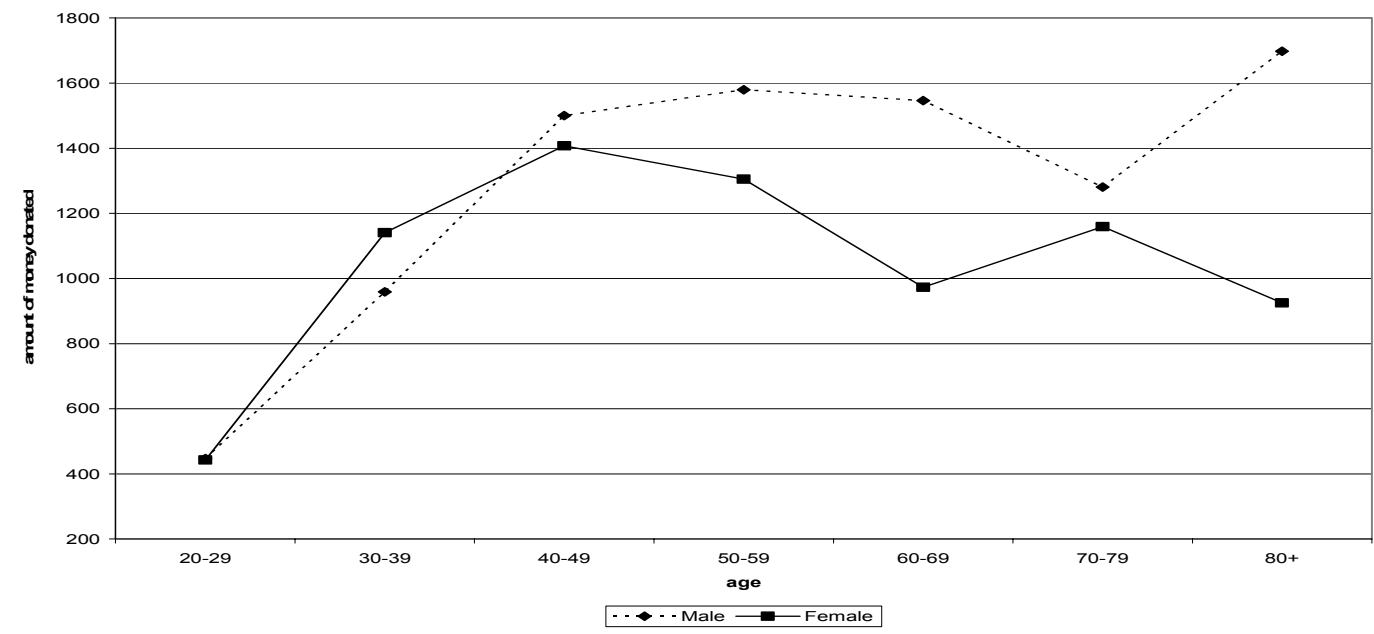

